\title{
LAS ESCRIBANÍAS EN LA CIUDAD DE MURCIA A FINES DE LA EDAD MEDIA
}

\author{
Antonio Gomariz Marín
}

\section{RESUMEN}

En este artículo se realiza un completo análisis sobre los escribanos que ejercían su profesión en la ciudad de Murcia a finales del siglo XV y comienzos del XVI. Este estudio se centra en los escribanos del número y los reales, nombrados por el concejo y por los monarcas, respectivamente. Dentro de este último grupo, se aborda las escribanías relacionadas con la recaudación de las rentas reales (sobre todo las aduanas) y con la justicia.

Se efectúa una identificación exhaustiva de los titulares de las escribanías, sus funciones, la forma de acceso al cargo, vínculos familiares, nivel socioeconómico, etc.

Se analiza con detalle las formas de transmisión del oficio, el grado de patrimonialización de éste, los exámenes, el tráfico de influencias en el seno del concejo para la provisión de estos empleos y, finalmente, los conflictos que su actuación ocasionaba entre sus convecinos.

Palabras clave: Escribanías, notarías, concejo, Murcia, Edad Media, Edad Moderna, siglo XV, siglo XVI, sociedad.

\begin{abstract}
In this article we carry out a complete análisis about notaries who Works in the town of Murcia in the Late Middle Ages. We study the «escribanos del número» and the royal notaries, appointed by the town council and the monarchy. Inside this group, we approach the notaries related to the collecting of royal taxes (custom-houses) and justice.

An exhaustive characterization is accomplished of the members of this profession, their duty, the way of accesing to the post, family ties, social and economic level, etc.

We analyze on detail the transmission mode of the post, heritage, exams, peddling of political favours in the council and, finally, conflicts with their fellow neighbours.

Key words: Notaries, council, Murcia, Late Middle Ages, Early Modern Ages, $\mathrm{XV}^{\text {th }}$ century, XVI ${ }^{\text {th }}$ century, society.
\end{abstract}


Los investigadores que consultan las fuentes documentales de época bajomedieval conservadas en los archivos municipales tropiezan con los nombres de unos profesionales de la escritura a los que debemos la casi totalidad de los documentos que han sobrevivido al paso del tiempo y a la desidia de los hombres. No existen estudios completos y detallados sobre estos oficiales que ejercieron su profesión en la ciudad de Murcia en los siglos XIV y XV, por lo que este trabajo, centrándose entre 1480 y 1515, intenta dar respuesta a una serie de cuestiones: identificación de los titulares de las diversas escribanías, forma de acceso al cargo, relaciones con el concejo y con sus convecinos, lazos familiares, etc.

Teniendo en cuenta lo específico de la documentación empleada, consistente en actas capitulares, legajos y cartularios reales custodiados en el Archivo Municipal de Murcia, así como cartas reales procedentes del Archivo General de Simancas, este artículo aborda únicamente el estudio de las escribanías laicas de la ciudad de Murcia, dejando de lado las eclesiásticas ${ }^{1}$.

A finales del siglo XV, existían en la ciudad de Murcia varios tipos de escribanías laicas: las del número, cuyo nombramiento correspondía a los regidores, y las del rey, que comprendían las relacionadas con la recaudación de las rentas reales y las tres escribanías del juzgado.

\section{A) ESCRIBANOS DEL NÚMERO}

Desde la época de Alfonso X correspondía el nombramiento de los 18 escribanos del número al concejo murciano ${ }^{2}$, personas que debían reunir varias condiciones para ejercer el oficio: mayor de 18 años, no padecer ninguna enfermedad que le incapacitase para desempeñar la profesión, honradez, buena fama ${ }^{3}$, católico, laico, situación económica sol-

1 OLIVARES TEROL, Ma JOSÉ: «Los Notarios de la Escribanía y Audiencia episcopales de la diócesis cartaginense durante el siglo XVI», Murgetana n ${ }^{\circ}$ 88, Murcia 1994, págs. 103-125. La única noticia hallada en la documentación consultada en el Archivo Municipal de Murcia sobre estos escribanos se reduce a un mandato del pesquisidor a los escribanos del número que también ostentaban escribanías apostólicas ordenándoles que optasen por uno de los dos oficios, so pena de perder la escribanía del número, Acta Capitular (en adelante A.C.) 1492, 18-IX-1492, fol. 79 r. A pesar de que varios escribanos del número eran también notarios apostólicos, como Pedro López, Alonso Belzunce, Bernardino de Pina o Alonso Bernal de Palomeque, solamente se ordenó a uno de ellos, Francisco del Castillo, que «no vsase de su escriuania apostolica, pues hera escriuano del numero de esta çibdad», A.C. 1492, 20-IX-1492, fol. 80 r. Por lo que se refiere a los escribanos del Santo oficio, dos de ellos se avecindan en Murcia: Alonso Fernández de Mojados, procedente de Avila, A.C. 1500, 22-IX-1500, fol. 52 v, y Francisco de la Plaza, procedente de Cuenca, A.C. 1503, 1-VIII-1503, fol. 38 r. En octubre de ese año obtendría una escribanía del juzgado, 17-X-1503, fols. 74 r-v.

2 RODRÍGUEZ LLOPIS, MIGUEL: «La Escritura y el Poder. La emisión de documentos en la sociedad murciana bajo-medieval», AREAS n 9, págs. 12-13, Editora Regional Murciana, Murcia 1988, págs. 9-24. Privilegio confirmado por Juan II en 1424, ABELLÁN PÉREZ, JUAN: «El concejo murciano de Junio de 1429 a Junio de 1430. Su estructura», Miscelánea Medieval Murciana, vol. V, págs. 121-157, Murcia 1980, Ap. Doc., doc. 1 , pág. 144 .

3 El concejo intentó privar de su escribanía a Juan Piñero, acusado de bastardía, A.C. 1503, 5-VIII-1503, fol. 43 v y en 1515 era interrogado Luis Conde, hijo natural de Toribio Conde, alcalde del corregidor Pedro Gómez de Setúbal, «sy hera ligitimado para tener ofiçios publicos»; al presentar una habilitación real, fue aceptado como escribano, A.C. 1514, 24-IV-1515, fols. 145 v 146 r. 
vente $^{4}$, vecino y residencia en el lugar donde ejercía su profesión y, por último, una serie de conocimientos técnicos no concretados, suficientes para desempeñar la profesión ${ }^{5}$.

Las funciones de los escribanos del número eran muy amplias, «en la esfera judicial abarcaba toda serie de actos jurídicos, sin distinción entre asuntos civiles y mercantiles y en la vida privada y social abarcaría ventas, donaciones, capitulaciones matrimoniales, fianzas, inventarios de bienes, hidalguía, testamentos, etc.» ${ }^{6}$. Les correspondía el desempeño anual y por turno rotatorio de las escribanías anexas a los oficios de alcaldes de Hermandad, de la Huerta y sobreacequieros. Además, uno de los escribanos ejercía de forma vitalicia la más importante de las escribanías, la del concejo.

Se podía acceder a una escribanía del número por renuncia del anterior titular o por nombramiento de los regidores, caso que se hubiera producido una vacante y el titular no hubiese designado sucesor o éste hubiera perdido el oficio por algún delito 7 . Tal y como se puede observar en el cuadro $n^{\circ} 1$, de los 40 cambios en la titularidad de las escribanías registrados entre 1481 y 1515, 26 se producen por el sistema de la renuncia (65\%) y 14 por elección de los regidores $(35 \%)$. La práctica habitual y mayoritaria consistía en renunciar en manos del concejo la escribanía, proponiendo a alguien en su lugar, aduciendo motivos genéricos y casi nunca concretados que imposibilitaban al renunciante el ejercicio de la profesión; renuncia y designación de sucesor que casi siempre era aceptada por el concejo sin ninguna dificultad ${ }^{8}$.

4 En 1495 el concejo declara que una escribanía vacante «segund los preuillejos de esta çibdad ha de ser proveyda en los fijos de los onbres buenos vezinos de la dicha çibdad», A.C. 1495, 21-XI-1495, fols. 73 r-v.

5 PIQUERAS GARCÍA, M MELÉN: «Cotos de los escribanos en Murcia durante 1472», Homenaje al prof. Juan Torres Fontes, vol. II, pág. 1305, Universidad de Murcia y Academia Alfonso X el Sabio, Murcia 1987, págs. 1303-1313.

6 PIQUERAS GARCÍA, Ma BELÉN: Ob. cit., pág. 1306. Su papel en el cobro de las alcabalas era primordial. Debían comunicar las enajenaciones de bienes raíces al arrendador de la alcabala de heredades. Frecuentemente sus funciones eran usurpadas por los escribanos reales y apostólicos, lo que motivó que en las Ordenanzas de los Escribanos Públicos de Sevilla, aprobadas por los Reyes Católicos en 1492, se dispusiera que los escribanos del número eran los únicos que podían intervenir en «todos los contractos de compras e ventas e troques e cambios e de çensos e arrendamientos...e de todas e qualesquier enajenaciones de bienes», GARCÍA ULECIA, ALBERTO: «El papel de corredores y escribanos en el cobro de las alcabalas», Historia, Instituciones, Documentos, (en adelante H.I.D.) n ${ }^{\circ} 13$, Sevilla 1986, págs. 89-110.

7 Hacia 1490 tres escribanos del número, Pedro de Alcaraz, Bartolomé Rodríguez y Lope de Santa María fueron condenados como herejes por la Santa Inquisición e inhabilitados para el ejercicio de su profesión, siendo sus escribanías confiscadas en beneficio del fisco real; al concejo murciano le llegaron rumores acerca de que «sus altezas an de proueher de los dichos ofiçios y ynpiden a esta çibdad la prouision que a fecho de las dichas escriuanias que asy vacaron, lo qual es en perjuyzio de los preuillejos de la dicha çibdad», A.C. 1490, 3-I-1491, fols. 67 r-v. Se envió un mensajero a la corte que consiguió, con la mediación del antiguo corregidor mosén Juan Cabrero, camarero real, que los monarcas confirmaran a los que había designado el concejo para cubrir dichas vacantes, los cuales las tenían «en encomienda por el conçejo de la dicha çibdad», 1491-II-9, Sevilla, Legajo $4.272 n^{\circ}$ 86. Los nuevos escribanos eran Francisco de Palazol, Juan Rodríguez de Bustamante y Antón Sevillón. Otro escribano del número también fue inhabilitado por el Santo Oficio por esta época, Rodrigo Sevillano, y el concejo nombró para sustituirle a Fernán Pérez de Monzón, A.C. 1490, 7-IV-1491, fols. 109 r 110 r.

8 Las razones expuestas en las renuncias eran poco variadas: «por quanto el esta ocupado asy de enfermedad como de otras cosas e no puede regir ni exerçer el dicho ofiçio», «por çiertas ocupaçiones» que imposibilitaban al titular el desempeño del oficio, por ausencia obligada de la ciudad, por «algunas dolençias y enfermedades», «por estar ocupado en negoçios de su fasienda e otras cosas que le ynpidian para vsar e soliçitar el dicho ofiçio», 
Cuadro n ${ }^{\circ} 1$

Escribanías del número de la ciudad de Murcia (1481-1515

\begin{tabular}{|c|c|c|c|c|}
\hline & NOMBRE & MODO DE ACCESO & FECHA & FUENTE \\
\hline \multirow[t]{4}{*}{1} & Juan Riquelme & & & \\
\hline & Alfonso Sevillano & Renuncia del anterior & 19-I-1481 & A.C. 1480 , fols. 84 v 85 v \\
\hline & Juan de la Cueva & Nombramiento Concejo & 20-VIII-1491 & A.C. 1491 , fols. $29 \mathrm{r}-\mathrm{v}$ \\
\hline & Juan de Tordesillas & Renuncia del anterior & 5-IX-1497 & A.C. 1497 , fols. 33 v 34 v \\
\hline \multirow[t]{2}{*}{2} & Antón Fernández & & & \\
\hline & Bernardino de Pina & Renuncia del anterior & $2-X-1484$ & A.C. 1484 , fols. $47 \mathrm{r} 48 \mathrm{v}$ \\
\hline \multirow[t]{5}{*}{3} & Juan Núñez de Astudillo & & & \\
\hline & Rodrigo Sevillano & Renuncia del anterior & $23-X-1484$ & A.C. 1484 , fol. 56 r \\
\hline & Fernán Pérez de Monzón & Nombramiento Concejo & 7-IV-1491 & A.C. 1490 , fols. 109 r 110 r \\
\hline & Bartolomé Fdez de Alarcón & Nombramiento Concejo & 17-XII-1496 & A.C. 1496 , fols. $91 \mathrm{r}-\mathrm{v}$ \\
\hline & Diego de Soria & Renuncia del anterior & 29-VIII-1508 & A.C. 1507 , fol. $102 \mathrm{v}$ \\
\hline \multirow[t]{2}{*}{4} & Pedro de Santa María & & & \\
\hline & Alfonso Rguez de Alcaraz & Nombramiento Concejo & $28-\mathrm{V}-1485$ & A.C. 1484 , fol. 144 r \\
\hline \multirow[t]{3}{*}{5} & Bartolomé Coque & Nombramiento Concejo & 8-XI-1488 & A.C. 1488 , fol. $86 \mathrm{r}$ \\
\hline & Juan del Castillo & Renuncia del anterior & 12-III-1510 & A.C. 1509 , fols. $137 \mathrm{r}-\mathrm{v}$ \\
\hline & Luis Conde & Renuncia del anterior & 24-IV-1515 & A.C. 1514 , fols. $145 \mathrm{v} 146 \mathrm{r}$ \\
\hline \multirow[t]{2}{*}{6} & Fernán Yáñez & & & \\
\hline & Alonso Belzunce & Nombramiento Concejo & 8-XI-1488 & A.C. 1488 , fol. $86 \mathrm{r}$ \\
\hline \multirow[t]{2}{*}{7} & Fernando del Castillo & & & \\
\hline & Francisco del Castillo & Renuncia del anterior & 7-III-1491 & A.C. 1490 , fols. 94 v 95 r \\
\hline \multirow[t]{4}{*}{8} & Pedro Núñez & & & \\
\hline & Fernando del Castillo & Renuncia del anterior & 16-VIII-1491 & A.C. 1491 , fols. $28 \mathrm{r}-\mathrm{v}$ \\
\hline & Francisco Pérez Beltrán & Nombramiento Concejo & 5-XII-1495 & A.C. 1495 , fols. 82 v 83 r \\
\hline & Pedro Ibáñez & Renuncia del anterior & $30-V I-1506$ & A.C. 1506 , fols. 6 × $7 \mathrm{r}$ \\
\hline \multirow[t]{4}{*}{9} & Antón Rodríguez & & & \\
\hline & Antón Bernad & Nombramiento Concejo & 3-XI-1492 & A.C. 1492,124 v $125 \mathrm{r}$ \\
\hline & Martín Lorenzo & Renuncia del anterior & $7-V-1496$ & A.C. 1495 , fols. 165 v $166 \mathrm{r}$ \\
\hline & Diego Pellicer & Nombramiento Concejo & 9-IX-1508 & A.C. 1507 , fols. 108 r 109 r \\
\hline
\end{tabular}




\begin{tabular}{|c|c|c|c|c|}
\hline \multirow[t]{2}{*}{10} & Juan Jiménez de Medrano & & & \\
\hline & Juan de Medina & Renuncia del anterior & 3-XI-1498 & A.C. 1498 , fol. $70 \mathrm{v}$ \\
\hline \multirow[t]{5}{*}{11} & Alonso de Palazol & & & \\
\hline & Francisco de Valcárcel & Renuncia del anterior & 23-III-1499 & A.C. 1498,110 v $112 \mathrm{r}$ \\
\hline & Diego de Soria & Renuncia del anterior & 31-III-1500 & A.C. 1499 , fol. $144 \mathrm{v}$ \\
\hline & Pedro López & Renuncia del anterior & $3-X-1500$ & A.C. $1500,54 \mathrm{v}$ \\
\hline & Pedro López & Renuncia del anterior & 26-III-1513 & A.C. 1512 , fols. 86 r 87 r \\
\hline \multirow[t]{3}{*}{12} & Luis Ruíz & & & \\
\hline & Alonso Bernad de Palomeque & Renuncia del anterior & $18-\mathrm{V}-1499$ & A.C. 1498 , fols. 125 v $127 \mathrm{r}$ \\
\hline & Martín de Borovia & Nombramiento Concejo & 4-XI-1514 & A.C. 1514 , fol. $71 \mathrm{r}$ \\
\hline \multirow[t]{3}{*}{13} & Alonso de Auñón & & & \\
\hline & Juan Piñero & Renuncia del anterior & $12-\mathrm{X}-1499$ & A.C. 1499 , fols. $66 \mathrm{r}-\mathrm{v}$ \\
\hline & Simón Periñíguez & Renuncia del anterior & 6-III-1507 & A.C. 1506 , fols. 115 r $116 \mathrm{r}$ \\
\hline \multirow[t]{4}{*}{14} & Alfonso Pérez de Monzón & & & \\
\hline & Pedro López & Renuncia del anterior & 15-IV-1469 & A.C. 1468 \\
\hline & Diego López & Renuncia del anterior & $3-X-1500$ & A.C. 1500 , fol. $54 \mathrm{v}$ \\
\hline & Martín de Jaca & Renuncia del anterior & 26-II-1512 & A.C. 1511, fol. $111 \mathrm{r}$ \\
\hline \multirow[t]{3}{*}{15} & Lope de Santa María & & & \\
\hline & Antón Sevillón o Sevillano & Nombramiento Concejo & 9-II-1491 & Legajo $4.272 \mathrm{n}^{\circ} 86$ \\
\hline & Garci Pérez de Bonmaitín & Renuncia del anterior & 28-IV-1506 & A.C. 1505 , fols. $130 \mathrm{r}-\mathrm{v}$ \\
\hline \multirow[t]{2}{*}{16} & Diego Riquelme & Nombramiento Concejo & 10-VII-1464 & A.C. 1464 \\
\hline & Bartolomé de Borovia & Renuncia del anterior & 3-VII-1507 & A.C. 1507 , fol. $9 \mathrm{v}$ \\
\hline \multirow[t]{3}{*}{17} & Bartolomé Rodríguez & & & \\
\hline & Juan Rguez de Bustamante & Nombramiento Concejo & 9-II-1491 & Legajo $4.272 \mathrm{n}^{\circ} 86$ \\
\hline & Francisco de Contreras & Renuncia del anterior & 18-XI-1508 & A.C. 1507 , fol. 158 r \\
\hline \multirow[t]{3}{*}{18} & Pedro de Alcaraz & & & \\
\hline & Francisco de Palazol & Nombramiento Concejo & 9-II-1491 & Legajo $4.272 n^{\circ} 86$ \\
\hline & Juan de Segovia & Renuncia del anterior & 2-III-1510 & A.C. 1509 , fols. $130 \mathrm{r} 131 \mathrm{r}$ \\
\hline
\end{tabular}


Aunque era preceptivo la realización de un examen en el que el beneficiario de la renuncia debía demostrar su capacidad técnica para el correcto ejercicio del oficio, éste raramente se hacía, limitándose el concejo a aprobar la renuncia, calificando al peticionario de «onbre abille e sufiçiente e byen sabido en el dicho ofiçio de escriuano» o de «buen escriuiente y persona de buen saber y conçiençia y abile y sufiçiente para el dicho ofiçio» o de «persona de buena fama y trato e conversaçion» o «visto que aquel es natural de esta çibdad e onbre fijodalgo e de buen seso»?.

En el periodo estudiado, el concejo se opuso en dos ocasiones a la renuncia de la escribanía, procedimiento que encubría en la mayoría de los casos la venta del oficio ${ }^{10}$. En 1500 el concejo se mostró reticente a aceptar la renuncia que Francisco de Valcárcel había hecho de su escribanía en favor de Diego de Soria; justificando su negativa en el hecho de que Soria no era vecino de Murcia y que «enteruenia en la dicha renunçiaçion dineros». Tras una concienzuda investigación que concluyó que no había pruebas suficientes que demostrasen la compra de la escribanía y tras el avecindamiento de Diego de Soria, éste fue aceptado como escribano del número ${ }^{11}$.

La otra ocasión se produce en 1510, cuando el concejo se lamenta que los escribanos del número renuncian sus oficios «en fauor de otras personas que son moços y no tienen tanta abilidad como ellos e ynportunan a los dichos señores justiçia, regidores que les prouean de los dichos ofiçios». Se promulgó una ordenanza en la que se les prohibía la designación de sus sucesores en las renuncias, debiendo desempeñar el oficio hasta su muerte, momento en el que el concejo nombraría a su sucesor para cubrir la vacante. Quizá la venta de escribanías había llegado hasta tal punto que los nuevos titulares no pertenecían en su totalidad al reducido grupo de cuantiosos y hombres buenos que, hasta entonces, habían nutrido el cuerpo de escribanos ${ }^{12}$.

Si por alguna razón se producía alguna vacante en las escribanías, el concejo procedía al nombramiento del titular. En 1492, como existían varias escribanías en esta situación, se anunció la celebración de un examen para proveer al nombramiento de sus titulares. Aunque los regidores se apresuraron a certificar mediante un solemne juramento que «bien e lealmente, guardando sus conçiençias, daran sus votos al que les paresçiere que lo deven

\footnotetext{
«por algunas cabsas que le ocurren», «por ocupaçion de mis enfermedades de riñones como de la vista», «por mis pecados a mucho tienpo que yo estoy cargado del mal de la gota y en la cama», A.C. 1491, 16-VIII-1491, fols. 28 r-v; A.C. 1497, 5-IX-1497, fols. 33 v 34 v; A.C. 1498, 3-XI-1498, fol. 70 v, 23-III-1499, fols. 110 v 112 r y 18-V-1499, fols. 125 v 127 r; A.C. 1499, 20-VI-1500, fols. 186 r-v; A.C. 1509, 12-III-1510, fols. 137 r-v y A.C. $1512,26-$ III-1513, fols. 86 r 87 r.

9 A.C. $1492,3-X I-1492$, fols. 124 v 125 r; A.C. 1497, 5-IX-1497, fols. 33 v 34 v; A.C. 1506, 6-III-1507, fols. 115 r 116 r y A.C. $1507,3-$ VII-1507, fol. 9 v.

10 RODRÍGUEZ LLOPIS, MIGUEL: Ob. cit, pág. 14.

11 A.C. 1499 , 14-III-1500, fols. 135 r 137 v y 31-III-1500, fol. 144 v.

12 A.C. 1509, 2-III-1510, fols. 130 r 131 r. En contra de su propia ordenanza, pocos días después el concejo aceptaba la renuncia de Bartolomé Coque en favor de Juan del Castillo, 12-III-1510, fols. 137 r-v. A partir de ese momento las renuncias que se registran no designan a su sucesor: 26-II-1512, 26-III-1513, 4-XI-1514 y 24-IV1515. Desgraciadamente la documentación silencia en la mayoría de los casos el parentesco o la procedencia de los nuevos escribanos. Sin embargo, resulta muy revelador que dos de ellos, Juan de Segovia y Juan de Jaca, que consiguen el oficio en 1510 y 1512, sean hijos de importantes carniceros y ganaderos de la ciudad, enriquecidos con el abastecimiento en exclusiva de este producto.
} 
dar e tiene abilidad para ello» ${ }^{13}$, nunca se efectuó dicho examen y los dos nombramientos siguientes se produjeron por designación directa de los regidores y del corregidor, sin registrarse ninguna votación ni deliberación sobre el asunto ${ }^{14}$.

En 1495 sí que se celebró un examen para cubrir la vacante de la escribanía del difunto Fernán Pérez del Castillo, presentándose a la prueba 9 candidatos que, en presencia de dos escribanos del número, realizaron un ejercicio consistente en la redacción de «algunos recabdos de testamentos e obligaçiones e poderes e cartas de vendida y otros recabdos y viendo sus letras y oyendoles leer». Esta numerosa concurrencia a la prueba nos indica lo atractiva que debía resultar esta profesión, la falta de oportunidades laborales que satisfaciesen las expectativas vitales de un grupo relativamente numeroso de vecinos y el tráfico de influencias que debía producirse en el seno del concejo para la provisión de estos empleos. Los regidores, como no podía ser menos, juraron que elegirían a la persona que «les paresçiere que tenia mas abilidad y sufiçiençia y mereçimiento para el dicho ofiçio», comunicando su nombre en secreto al corregidor y al escribano del concejo, quien iría anotando los votos de cada uno de los regidores ${ }^{15}$.

Tenemos constancia de exámenes en 1508 y 1510, pero en ninguno de los casos se indica los términos de la prueba. En la primera ocasión, los diputados del concejo, un regidor y el escribano del concejo, deciden que el aspirante, que había obtenido la escribanía mediante la renuncia del anterior titular, era buen escribiente, sabía leer bien y era de «buen seso», por lo que creían que sería buen oficial ${ }^{16}$. Pero la celebración de tales pruebas es algo anecdótico, únicamente conocemos tres en más de 25 años y es que «la habilidad en el arte de escribir no constituyó el rasgo esencial del escribano; de hecho, se limitó la posibilidad de acceder a tal título a los miembros de un reducido grupo social, estrechamente ligados a la nobleza, la Iglesia y el patriciado urbano» ${ }^{17}$.

13 A.C. $1491,15-\mathrm{V}-1492$, fol. 139 r

14 Nombramiento de Antón Bernad y Miguel de Contreras, A.C. 1492, 3-XI-1492, fols. 124 v 125 r y 23-IV1493, fols. 207 r-v. En 1488, para cubrir dos escribanías vacantes, el concejo ordenó a su escribano que anotase los nombres de los solicitantes, jurando los regidores que votarían a «aquella persona que en sus conçiençias que entendieren que mas conviene al dicho ofiçio e honra de esta çibdad» y si alguno de los candidatos tuviese igual número de votos se sortearía entre ellos. Se presentaron ocho aspirantes: Bartolomé Coque, Alonso de Belzunce, Julián de Atienza, Fernando del Castillo, Alonso Sánchez de las Doncellas, Fernando Laso, Andrés de la Sisla y Juan de la Cueva; eligiendo el concejo a los dos primeros, A.C. 1488, 8-XI-1488, fol. 86 r, 17-XI-1488, fols. 90 v 91 r y 18-XI-1488, fols. 92 r 93 r.

15 A.C. 1495, 21-XI-1495, fols. 73 r-v y 5-XII-1495, fols. 82 v 83 r. Se presentaron Alonso de Palomares, Alonso de Solís, Bartolomé Fernández de Alarcón, Martín Lorenzo, Diego García, Juan de Tordesillas, Juan Yáñez, Juan de Mergelina y Francisco Pérez Beltrán, siendo este último el elegido. Era hijo del anterior escribano del concejo, pues «tuvo muchos mas votos que ninguno de todos los otros». Aunque las cualidades técnico-profesionales se conseguían en el seno de las tiendas de escribanías públicas, regentadas por un notario, «la realización práctica de esta prueba no será sino la culminación de una gran trama de intereses familiares y de clientela de las personas que monopolizaban los cargos concejiles», PARDO RODRÍGUEZ, M ${ }^{\mathrm{a}}$ LUISA: «Exámenes para escribano público en Carmona en 1501 y 1502», H.I.D., nº 20, Sevilla 1993, págs. 303-312, pág. 307.

16 Examen de Francisco de Contreras, A.C. 1507, 11-XI-1508, fol. 154 r y 18-XI-1508, fol. 158 r. El de Juan del Castillo, A.C. 1509, 12-III-1510, fols. 137 r-v y 23-III-1510, fols. 141 r 142 r.

17 RODRÍGUEZ LLOPIS, MIGUEL: Ob. cit., pág. 10. 
Asimismo, se produjeron otros nombramientos por parte del concejo sin que tuviera lugar ningún tipo de examen ni votación, lo que parece demostrar unos acuerdos previos entre los regidores que evitarían enfrentamientos y discusiones en el seno del concejo. Las distintas familias que monopolizaban el regimiento se repartirían los nombramientos de los futuros escribanos, fenómeno del que por supuesto no hay constancia documental, con lo que todas conseguían aumentar sus clientelas personales y su influencia social ${ }^{18}$.

Por uno u otro procedimiento, una vez nombrado por el concejo o aceptada la renuncia del anterior titular, el nuevo escribano del número tomaba posesión de su cargo ante el concejo, jurando que usaría bien y lealmente de este oficio, sin fraude, engaño ni colusión alguna, guardaría el servicio real, sus rentas, derechos y ordenamientos, el bien y el pro común de la ciudad, comprometiéndose además a no cobrar ninguna cantidad al concejo murciano de los «abtos» y escrituras que afectasen a éste ni a cobrar más derechos de los estipulados por los aranceles y los ordenamientos reales, a guardar la ordenanza municipal acerca de las particiones de bienes y a respetar el secreto de las partes, excepto si fuese en deservicio real o daño del reino ${ }^{19}$.

Un problema relacionado con el procedimiento de provisión de las escribanías del número sería conocer en qué grado se encontraban estos oficios patrimonializados, o lo que es lo mismo, en qué medida intervenía la herencia o la sucesión familiar en ellos. Si analizamos la lista de los titulares de las 18 escribanías que aparecen en el cuadro $\mathrm{n}^{\circ} 1$ veremos que el concejo, a primera vista, logró evitar su patrimonialización, pues en muy pocas ocasiones sucede como titular de la escribanía el hijo al padre, aunque ignoramos otros posibles lazos familiares entre el renunciante y el beneficiario. Además de que es

18 Tales nombramientos se producen en 1496 y 1508 para cubrir las vacantes dejadas por Fernán Pérez de Monzón y Martín Lorenzo, respectivamente. En 1496 Pérez de Monzón llevaba más de un año ausente de la ciudad, incluso se había avecindado en León, donde era escribano del número, por lo que el concejo nombró a Bartolomé Fernández de Alarcón, que ya se había examinado en 1495 y fue «elejido para el primero ofiçio que vacase del numero», A.C. 1496, 17-XII-1496, fols. 91 r-v. En septiembre de 1497 Pérez de Monzón consiguió una escribanía del juzgado de la ciudad de Murcia, posiblemente por compra, recuperando además su escribanía del número, instalándose en Murcia en junio de 1498. Un año después consta que había huido de la ciudad, ya que había matado a su esposa, Úrsula Pérez, y a su criado, Pedro de Narváez, por haber cometido adulterio (1500-IV-, Sevilla, Archivo General de Simancas — en adelante AGS -, Registro General del Sello - en adelante RGS - , sin foliar). Pérez de Monzón pudo recuperar sus oficios en fecha indeterminada, aunque debió ser más o menos hacia 1501, ya que en esta fecha conseguía un perdón real por la muerte de Narváez (1501-VII-30, Granada, AGS, RGS, sin foliar) y en 1503 renunciaba la escribanía del juzgado y en 1508 la del número en favor de Diego de Soria, A.C. 1507, 29-VIII-1508, fol. 102 v. La vacante de Martín Lorenzo en 1508 fue mucho menos accidentada. Su sucesor, Diego Pellicer, fue nombrado por el concejo, influído por la recomendación del adelantado Pedro Fajardo: «tengole mucho amor y buena voluntad por algunos seruiçios que de el tengo resçebidos. Pidos señores por merçed ayays por bien de proveer de la escrivania al dicho Diego Pelliçer...porque conosca de mi que en obras le pago el amor que le tengo», ?-VIII-25, Vélez, Legajo $4.287 \mathrm{n}^{\circ} 68$. Publicada por RODRÍGUEZ LLOPIS, Ob, cit., pág. 14, A.C. 1507, 9-IX-1508, fols. 108 r 109 r. No fue el único caso, aunque esta vez sin éxito, pues el arzobispo de Toledo escribió al concejo murciano recomendándole a Fernando de Funes, su criado, para una escribanía del número, vacante al haber sido condenado el anterior escribano, Lope de Santa María, por la Inquisición, 149..-VII-31, Jaén, Legajo 4.287 n 24. Otros nombramientos sin examen ni votación: Martín de Borovia en lugar del difunto Alonso Bernad de Palomeque y Luis Conde en lugar de Juan del Castillo, A.C. 1514, 4-XI-1514, fol. 71 r y 24-IV-1515, fols. 145 v 146 r.

19 Juramento de Antón Bernad, A.C. 1492, 6-XI-1492, fols. 127 v 128 r. 
imposible conocer los cambios en los apellidos, que es factible que se hayan producido. Unicamente aparecen dos casos de herencia familiar. Es uno el de Hernando del Castillo, que renuncia en 1491 su escribanía en su hijo Francisco ${ }^{20}$, y el otro el de Pedro López, que hace lo mismo en 1500 en su hijo Diego. Consiguió otra escribanía por renuncia de Diego de Soria y la renuncia en 1513 en su otro hijo, también llamado Pedro ${ }^{21}$.

En Castilla no existían instituciones de enseñanza superior o específicas, como en Italia, que proporcionasen al futuro escribano los conocimientos técnicoculturales que le capacitasen para el ejercicio del oficio, éstos se conseguían en las escribanías públicas, regentadas por un notario, quien establecía una relación contractual de aprendizaje entre maestro y discípulo. Por ello, era corriente que los hijos aprendieran el oficio en la escribanía del padre. Lo extraordinario es que no lograran los escribanos del número transmitir en su totalidad la profesión a sus hijos ${ }^{22}$.

Pese a esta aparente falta de patrimonialización, existen una serie de familias en las que, al menos dos de sus miembros, son titulares de escribanías del número entre 1480 y 1515 .

En primer lugar los Sevillano o Sevillón, como también se les denomina en la documentación. Alonso Sevillano, escribano del número entre 1481 y 1491, y su hermano Rodrigo, también escribano entre 1484 y 1491, tuvieron problemas con la Inquisición, pues sabemos que en 1493 Alonso estaba acusado por ésta «del crimen de la heretica pravedad e llamado sobre ello, se a absentado», aunque dos años antes el concejo ya suponía que su escribanía iba a quedar vacante ${ }^{23}$. Finalmente, encontramos a otro miembro de esta familia como titular de una escribanía del número y otra del juzgado. Se trata de Antón Sevillón o Sevillano, a quien, al parecer, no afectaron los problemas de sus parientes con la Inquisición; incluso, como ya hemos visto, se benefició de la actividad inquisitorial, al conseguir la escribanía de Lope de Santa María, que la había perdido, precisamente, víctima del Santo Oficio. Otra familia con representación en el notariado murciano serían los Borovia: Bartolomé y Martín ${ }^{24}$. Los Palazol y los Pérez Beltrán llevaban siendo escribanos del número de la ciudad de Murcia durante muchísimo tiempo: en 1426 el concejo

20 A.C. 1490, 7-III-1491, fols. 94 v 95 r. En 1510, otro de sus hijos, Juan, consigue la escribanía de Bartolomé Coque por renuncia de éste, A.C. 1509, 12-III-1510, fols. 137 r-v.

21 A.C. $1500,3-\mathrm{X}-1500$, fol. 54 v y A.C. 1512 , 26-III-1513, fols. 86 r 87 r.

22 El único caso en el que se nos dice el modo por el que el nuevo escribano adquirió los conocimientos técnicos nece-sarios tiene lugar en 1499 y se trata de la escribanía del concejo, que renuncia Alonso de Palazol en su hijo Francisco, afirmándose que éste «hera persona honrada y fijodalgo e buen escriviente e de buen trato e fama e conversaçion y tenia mucha abilidad e sufçiençia e sabiduria en el dicho ofiçio y mucha platica y memoria de los preuillejos e hordenanças e otros buenos vsos e costunbres de la dicha çibdad por se aver criado desde que fue en edad de ocho años en la camara e consystorio de la dicha çibdad con el dicho Alonso de Palazol su padre», A.C. 1498, 2-III-1499, fols. 102 v 103 v.

23 A.C. 1492, 23-IV-1493 y A.C. 1491, 20-VIII-1491, fols. 29 r-v. Su hermano escribió al concejo murciano notificándole que haría entrega de las escrituras de su hermano y lamentándose de la calamidad ocurrida en casa de éste, a causa de las malas compañías «y de como sus fijos quedan perdidos», s.XV-II-23, Murcia, Legajo $4.276 \mathrm{n}^{\circ}$ 53. Por esta época, el mismo Rodrigo Sevillano fue inhabilitado, perdiendo su escribanía, A.C. 1490, 7-IV-1491, fols. 109 r 110 r.

24 Eran hijos de un tal Pedro de Borovia, A.C. 1507, 3-VII-1507, fol. 9 v y A.C. 1514, 4-XI-1514, fol. $71 \mathrm{r}$. 
nombró como tal a Alfonso de Palazol, mientras que en 1430 Francisco Pérez Beltrán, cuyo padre también había sido escribano, sustituía al difunto Pedro Gómez de Alcaraz ${ }^{25}$. Los Palazol, padre e hijo, ejercen dos escribanías a la vez durante cierto tiempo. Alonso, el padre, hasta 1499 y Francisco, desde 1491 hasta 1510. Los dos desempeñaron sucesivamente el cargo de escribano del concejo. Por último, cabría resaltar a la familia de los Pérez Beltrán. En 1474 dos de ellos, Francisco y Diego, poseen dos escribanías ${ }^{26}$. Francisco fue incluso escribano del concejo hasta 1481. Aunque no pudieron transmitir su escribanía a otro Francisco Pérez Beltrán, el concejo le otorgó una tras superar un examen en 1495, y la estuvo desempeñando hasta 1506.

Cada cambio en la titularidad de las escribanías suponía un verdadero caos para la documentación generada por ésta. Como quedaba custodiada por el ex escribano o sus herederos se producían pérdidas, encubrimientos o destrucciones deliberadas de los documentos. Las instruciones dadas por los reyes en 1502 intentaban solucionar este problema. Se disponía que cuando se produjese una vacante en una escribanía, el corregidor y el escribano del concejo debían ir al domicilio del antiguo escribano y reunir todas las notas, registros y escrituras, sellarlas con un sello, depositarlas en un lugar seguro para ser entregadas a su sucesor, además de un memorial en el que se describía todo el proceso efectuado ${ }^{27}$. En 1506, el escribano Pedro López propone al concejo el cumplimiento de esta pragmática real y sugería que, cuando él falleciese, se nombrasen dos diputados que, con el escribano del concejo, anotasen en dos inventarios todas las escrituras custodiadas en su escribanía. Uno de ellos sería entregado a su sucesor en el oficio y el otro se depositaría en el arca del concejo. Los inventarios irían firmados por los diputados y el escribano del mismo. De este modo, explicaba, «porque cada e quando alguna persona pidiere a los tales notarios que mis escriuanias touieren alguna petiçion o escriptura o no la diere o dixere que no la falla, que la tal persona recorra al ynventario que vuestras merçedes touieren en su archin, por manera que las partes fallen razon de lo que pidieren e ante mi oviere pasado». El concejo aprobó la propuesta y acordó proceder del mismo modo con los otros escribanos del número ${ }^{28}$.

Los escribanos, además de sus retribuciones, cobraban una serie de derechos por dar fe de actos jurídicos de carácter privado, gozaban de una serie de privilegios, como la exención de determinados tributos, de ir a la guerra o de brindar hospedaje.

25 A.M.M., A.C. 1438, 7-II-1439.

26 PIQUERAS GARCÍA, Ma BELÉN: «Funcionamiento del concejo murciano...», pág. 44.

27 La pragmática se dió en Toledo, 12-VII-1502, Novísima Recopilación, Libro X, Título XXIII, Ley X. Este problema no era nuevo, pues en 1329 el concejo de Murcia consultó a Alfonso XI cómo proceder cuando moría un escribano, cuya documentación, con arreglo al Fuero Real, Tit. VIII, Ley IV, debía de quedar en poder de los alcaldes de la ciudad, que la entregarían a su sustituto, cosa que no sucedía en Murcia, por lo que este monarca ordenó que los herederos del escribano se quedasen con los registros y libros del difunto para venderlos públicamente al notario que más pagase por ellos y se repartiesen el producto de la venta, pero si alguno de los hijos era escribano, podía quedarse con las escrituras y registros de su padre, entregando a sus hermanos su valor, tasado por hombres buenos; en todo caso sería preferible que los libros fuesen a parar a manos de un solo notario y que no se repartiesen entre varios, así como que quedasen en poder de su hijo antes que de un extraño, 1329-II-26, Soria, publicado por FRANCISCO VEAS ARTESEROS: Documentos de Alfonso XI, C.O.D.O.M., VI, Academia Alfonso X el Sabio y C.S.I.C., Murcia 1997, Doc. CXX, págs. 126-132, nota 13, pág. LV.

28 A.C. 1505 , 17-II-1506, fols. 102 r-v. Curiosamente, dicha pragmática real no fue invocada por los interesados. 
La actuación profesional de los escribanos del número provocaba en algunas ocasiones las protestas del concejo o de los vecinos. Dos temas sobre todo centraban las quejas: el cobro de cantidades superiores en concepto de derechos a las estipuladas por los aranceles concejiles y sus ausencias de la ciudad. Por lo que se refiere a la primera cuestión, el concejo, para remediar tales abusos, fijaba los derechos exigibles por estos profesionales mediante un arancel ${ }^{29}$ y procedía al nombramiento de dos diputados, un regidor y un jurado, que tasarían las escrituras redactadas por los escribanos, imponiendo penas pecuniarias a los que cobrasen cantidades superiores a las permitidas o lo hicieran sin haber sido tasadas previamente por dichos diputados ${ }^{30}$.

De forma ocasional, por lo que no parece un fenómeno repetido, el concejo deploraba el absentismo de algunos de los escribanos del número que, a pesar de que no estaba permitido, eran vecinos de otras ciudades y residían permanentemente en ellas. El problema se describía en 1495 con tintes excesivamente dramáticos: «esta çibdad careçe de los dichos escriuanos y asy las justiçias como los vezinos de la dicha çibdad no fallan ante quien fagan sus abtos», ordenando el concejo que, en el plazo de un año, todos los escribanos regresasen y se avecindasen de nuevo, so pena de perder la escribanía ${ }^{31}$. Pero en 1506 vuelve a aparecer esta queja en el memorial que llevan los procuradores de Cortes. En éste se acusa a los 18 escribanos del número de absentismo laboral pues,

29 En 1492 se denunciaba que los escribanos exigían muchos derechos «de fazer las dichas partiçiones» pues «no tienen nonbrado salario ninguno, syno lo que quieren pedir». Se ordenó que, por hacer una partición de bienes en cuantía inferior a 10.000 mrs, el escribano cobraría 100 mrs; si era entre 10.000 y 20.000 mrs, cobraría 200 y, a partir de esa cantidad, no más de $300 \mathrm{mrs}$, so pena de perder el oficio durante un año, de devolver lo cobrado de más y las setenas, A.C. 1492, 3-XI-1492, fols. 125 r-v y A.C. 1493, 28-IX-1493, fol. 27 v. No se remedió este problema, pues en 1502 y a petición de un mensajero del concejo, los reyes ordenaban al corregidor que enviase al Consejo Real toda la información necesaria sobre el problema, pues «avnque la dicha çibdad sobre ello a ordenado moderando los tales abtos e derechos, syenpre se a corron-pido e deshordenado syn aver ninguna execuçion ni castigo» y que, mientras tanto, debía fijar tales derechos: 1502-VI-23, Toledo, Cartas Antiguas y Modernas - en adelante C.A.M. -, vol. V, n 76, Apéndice Documental, III.

30 Se nombró a tales diputados en: 19-XI-1491, 3-XI-1492, 14-XI-1493, 11-XI-1496, 23-V-1497, 20IV-1499, 14-XI-1500, 11-I-1502 y 22-VIII-1503. Su cometido era el siguiente: «para que hagan y apremien a los escriuanos de esta çibdad que no lleuen mas derechos de lo que la tabla manda y a los que lo contrario hisieren lo notyfiquen al señor corregidor, para que exsecute las setenas de los que mas lleuaren y, asymismo, para que tasen las escripturas que dieren sygnadas en vno con el escriuano del conçejo conforme a la tabla», A.C. 1493, 16-XI-1493, fols. 49 r-v. Casi un año después, el procurador síndico exigía al corregidor que hiciese cumplir a los escribanos el arancel de derechos, esgrimiendo para ello una carta real en la que se le ordenaba el envío al Consejo Real de todos los aranceles que se cobraban en la ciudad, pues el concejo se había quejado de que «la dicha çibdad e vezinos de ella han reçibido e reçiben mucha vexaçion e fatiga, asy de los que tienen el cargo de la justiçia en ella como de los escriuanos e otros ofiçiales que ay en la dicha çibdad, porque les fan lleuado e lleuan muchos derechos, penas e caloñas e escrituras e otros abtos e cosas que ante ellos pasan», 1494-IV-, Medina del Campo, AGS, RGS, fol. 312, Apéndice Documental, II; A.C. 1493, 10-V-1494, fols. 99 r-v. En 1503 se pregonó una pragmática real que regulaba los derechos que debían cobrar los jueces y escribanos, prohibiendo el cobro del derecho de las meajas en las ejecuciones (33 mrs por millar), 1503-V-13, Alcalá de Henares, Cartulario Real -en adelante C.R.- 1535-1554, fols. 163 r-v, A.C. 1503 , 4-XI-1503, fol. $81 \mathrm{r}$.

31 A.C. 1495, 4-VIII-1495, fol. 20 v y 21-XI-1495, fols. 73 v 74 r y A.C. 1496, 17-XII-1496, fols. 91 r-v. 
según se afirmaba, se dedicaban a otras actividades mercantiles quizá más lucrativas ${ }^{32}$. Los procuradores debían conseguir una disposición real que ordenase taxativamente a estos profesionales (excepto al del concejo) que se asentasen permanentemente según el horario fijado por el concejo en los lugares más públicos de la ciudad, tal y como se hacía en Toledo o Sevilla o, en caso contrario, que se permitiese al concejo de Murcia privarles de sus oficios y nombrar a otros como escribanos. La respuesta real fue más bien modesta, remitiendo el asunto al corregidor para que lo resolviese como le pareciera oportuno, de modo que los escribanos estuvieran siempre en lugares públicos a disposición de los que necesitasen de sus servicios, pero sin aludir para nada al permiso solicitado por el concejo para que se le permitiera privarles de su oficio. Dos motivos pesarían, sin duda, en la decisión real; de un lado, si se accedía a la petición concejil, se conculcaba el privilegio de Juan II que estipulaba el nombramiento vitalicio de los escribanos del número, y, de otro, se pondría completamente en manos de los regidores la suerte de estos profesionales, pues, arguyendo que no desempeñaban correctamente su trabajo, podían ser cesados libremente ${ }^{33}$.

Sobre el patrimonio de éstos y sus otras actividades económicas, la documentación es, desgraciadamente, muy escasa. Encontramos a algunos de ellos como propietarios de tierras, ya en la huerta de la ciudad ${ }^{34}$ o en el Campo de Cartagena, al ser beneficiarios de alguna de las donaciones que el concejo de Murcia estaba efectuando en esa época. Debemos señalar que tales donaciones de tierras no fueron numerosas ni especialmente extensas $^{35}$. La mayoría debían poseer algunos rebaños no demasiado importantes. Uno de ellos, Pedro López, era dueño de un rebaño de vacas lo suficientemente importante como para ocasionar daños de cierta magnitud en el regadío de la ciudad ${ }^{36}$. Otros probaron fortuna con el arrendamiento de las rentas concejiles, como Fernán Pérez de Monzón, que en 1506 ofreció 180.700 mrs por la más importante de las rentas concejiles, la Sisa, o Juan del Castillo, quien en 1512 pujó por las Salinas de Sangonera ${ }^{37}$. Quizá individualmente

32 «algunos e los mas de ellos entienden en sus fasiendas e en mercadurias e en otras cosas e, avnque vsan de los ofiçios no tan continamente como devian, de manera que muchas personas que quieren fazer abtos e contratos no los hallan en los lugares publicos para haser los dichos contratos e recabdos luego que se conçiertan con ellos, lo qual cavsa trabajo e peridia [sic] a muchas personas», A.C. 1505, 22-I-1506, fols. 104 r $105 \mathrm{r}$.

33 A.C. 1505, 17-I-1506, fol. 103 r y 1506-VIII-25, Valladolid, C.R. 1505-1514, fols. 7 v 8 r, Apéndice Documental, V.

34 En 1506 se autoriza al escribano Francisco del Castillo a construir un palomar «pues tiene la cantidad de tahullas que la hordenança de la çibdad manda», A.C. 1506, 21-VII-1506, fol. 15 r.

35 Se concedió al escribano del concejo la fadiga de 2 tahúllas en el Palomar, A.C. 1491, 1-X-1491, fol. 44 r; un secano de superficie indeterminada a Juan Rodríguez de Bustamante, A.C. 1500, 12-IX-1500, fol. 43 v; 134 Ha a Diego Riquelme en las proximidades del Cabezo Gordo, que fueron devueltas al concejo por el interesado en 1504, A.C. 1501, 23-XI-1501, fol. 84 v y A.C. 1503, 15-VI-1504, fol. 168 r; la Torre del Sordo a Alonso Bernad de Palomeque, A.C. 1509, 21-III-1510, fols. 140 r 141 r; 22 Ha en la Cañada de San Miguel a Pedro Domínguez, A.C. 1513, 18-II-1514, fol. 119 r y a Diego Pellicer un solar situado extramuros de la ciudad, en las proximidades de la Puerta Nueva, A.C. 1515, 8-I-1516, fols. 114 r 116 r. Sobre el tema de las donaciones de tierras, vid. MOLINA MOLINA, ÁNGEL LUIS: El campo de Murcia en el siglo XV, Academia Alfonso X el Sabio, Murcia 1989.

36 A.C. $1502,24-$ III-1503, fol. 209 r.

37 A.C. $1506,14-$ VII-1506, fol. 15 r y A.C. 1511 , 3-VI-1512, fol. 165 v. 
pudieron dedicarse al pequeño préstamo con interés, lo cierto es que, pese a la escasez de noticias, que sepamos, en al menos una ocasión, prestaron dinero al concejo ${ }^{38}$.

\section{B) ESCRIBANO DEL CONCEJO}

Esta escribanía era ejercida por uno de los 18 escribanos del número. Correspondía a los regidores la elección y nombramiento de este cargo vitalicio. Entre 1481 y 1515 ejercen este cargo dos personas: Alonso y Francisco de Palazol, padre e hijo. El primero fue elegido como tal por el concejo en 1481, sustituyendo al difunto Francisco Pérez Beltrán ${ }^{39}$; el segundo obtuvo el oficio por renuncia de su padre en marzo de 1499. El concejo aceptó la renuncia considerando al renunciante como «onbre viejo e padeçe algunas dolençias e enfermedades y le ynpiden el exerçiçio del dicho ofiçio» ${ }^{40}$.

Una vez nombrado como escribano mayor del concejo prestaba juramento ante éste. Sus cometidos eran los siguientes:

1) Redactaba y validaba toda la documentación que emanase del concejo: presentaciones de cartas al rey, memoriales, recudimientos reales, títulos de hidalguía, padrones vecinales, etc.

2) Asentaba por escrito en el libro de Actas todo lo tratado en las reuniones del concejo, para lo cual debía asistir a todas ellas.

3) Custodiaba los privilegios de la ciudad, escrituras y libros de Actas $^{41}$.

4) Anexa a este oficio se hallaba la escribanía de los ejecutores y todo lo perteneciente a ella, como fianzas de corredores y menestrales y todos los pleitos que se sustanciasen ante ellos por vía de apelación.

5) Le correspondía anotar en el libro correspondiente todas las denuncias y las penas impuestas por dañar los cultivos en la huerta y secano de la ciudad. Además, debía dar fe de todas las subastas de las prendas de los infractores que realizasen los ejecutores.

6) Su papel en el arrendamiento y recaudación de las rentas reales era notable. Asentaba por escrito las demandas presentadas por los arrendadores de las alcabalas ante los alcaldes ordinarios y los corregidores, el pregón en el que se anunciaba el cuaderno de las alcabalas, las almonedas efectuadas por los arrendadores menores de las prendas de los deudores, las cartas de recudimiento otorgadas por los arrendadores mayores a los menores, todos los actos realizados por los fieles nombrados por el concejo en las rentas reales.

38 Fernán Pérez de Monzón prestó 30.000 mrs destinados a la compra de cereal, A.C. 1502, 18-IV-1503, fol. $222 \mathrm{r}$.

39 A.C. 1480 , 19-I-1481, fols. 81 v 83 r.

40 A.C. 1498, 2-III-1499, fols. 102 v 103 v. Algunos días más tarde renunciaba a su escribanía del número (23-III-1499, fols. 110 v 112 r) y fallecía en octubre de ese mismo año, A.C. 1499, 15-X-1499, fol. 67 v.

41 En 1492 se le encargaba que hiciese «vn atril para que se tengan las escripturas en la sala», A.C. 1491, 1-VI-1492, fol. 146 r; en 1495 se construía una mesa «donde el escriuano thenga sus escrituras e las otras cosas que oviere menester quando los señores estan en su ayuntamiento» y se le ordenaba que trajese a la Casa de la Corte «el arca ginovisca» donde se custodiaban los privilegios de la ciudad, y que se encontraba en su domicilio particular, reforzándola con dos cerraduras más, A.C. 1494, 4-IV-1495, fol. 138 r. Obedeciendo las órdenes reales, las tres llaves de la misma fueron entregadas al corregidor, al regidor encargado del «sello y pendón» y al escribano del concejo, A.C. 1495, 23-VI-1495, fols. 2 r-v. 
7) Daba fe en los asuntos y las circunstancias más diversas. Por ejemplo, certificaba si los sobreacequieros estaban exentos de pagar acequiaje; averiguaba mediante testigos el daño ocasionado en las Salinas de Sangonera; para tasar con exactitud la onza de pan, en su presencia los ejecutores averiguan el número de onzas que se pueden obtener de una barchilla de trigo; para evitar los robos de leña perpetrados por criados y esclavos en la Huerta, los dueños de heredades debían pedir al escribano del concejo un albalá en el que figurara su nombre, los días que el criado o esclavo iba a ser enviado a por leña y el número de cargas; como los gorriones dañaban los cultivos y el concejo ofrecía una recompensa por cada 100 pájaros entregados, el escribano debía certificar que todos los pies de pájaros eran de tales aves ${ }^{42}$.

8) Debía asentar por escrito y certificar la validez de todos los arrendamientos de las rentas concejiles (subastas, fianzas, etc.).

9) Firmaba los libramientos del concejo para que fueran pagados por el mayordomo.

10) Acompañaba al alcalde de la Mesta.

11) Registraba los avecindamientos.

12) Tenían lugar ante él las obligaciones de las carnicerías ${ }^{43}$.

14) Era el receptor de las diversas penas pecuniarias, el tercio de las cuales pertenecía al concejo y se destinaba a la reparación de obras públicas.

Percibía una quitación anual con cargo a los fondos concejiles de 3.700 mrs, de los cuales correspondía a su salario 1.200, mientras que el dinero restante se destinaba a la compra de papel (2.000), de tinta y cera (500).

\section{C) ESCRIBANOS REALES}

Las escribanías del rey o de corte eran provistas por la monarquía. Los Reyes Católicos dispusieron en las Cortes de Toledo de 1480 que para desempeñar una escribanía real o de cámara era preceptivo la realización de un examen ante el Consejo Real «e fuere por ellos examinado e fallado que es abile e ydoneo para exercer el tal officio». Además, el título de escribano («la carta de escriuania») debía ir librada por tres letrados del Consejo Real por lo menos, y firmada por los reyes.

Se reservaba a los escribanos del número «los contratos de entre partes, las obligaciones y testamentos», mientras que los escribanos reales podían dar fe de otros actos judiciales fuera de la jurisdicción de la ciudad correspondiente ${ }^{44}$.

En esta época desempeñaban el oficio de escribano real en la ciudad de Murcia un número indeterminado de personas, la mayoría de los cuales eran también escribanos del número: Pedro López, Diego Riquelme, Bartolomé Coque, Juan Rodríguez de Bustamante, Antón Sevillón o Sevillano, Luis Romi, Francisco de Palazol, Alonso Belzunce, Bernardino

42 A.C. 1501, 31-VIII-1501, fol. 43 r, 18-IX-1501, fol. 50 r, 7-IV-1502, fol. 155 v; A.C. 1505, 22-XI-1505, fol. $71 \mathrm{r}$ y 16-XII-1505, fols. $90 \mathrm{v} 91 \mathrm{r}$.

43 Libro 32, fols. 83 v 85 v, RODRÍGUEZ LLOPIS, MIGUEL: Ob. cit., pág. 14, nota 20.

44 Cortes de Toledo, 1480, pet. 73, Cortes de los Antiguos reinos de León y Castilla, vol. IV, Madrid 18611882, págs. $146-147$. 
de Pina, Alonso Sánchez de las Doncellas, Juan Yáñez, Juan de Medina y Juan Fernández de Pineda ${ }^{45}$.

Aparte de los citados, de la mayoría de los cuales queda constancia documental de su nombramiento como escribanos reales, habría un grupo de personas en beneficio de las cuales el concejo murciano gestionó su nombramiento ante el Consejo Real, pues, de vez en cuando, desde Murcia se pedía a los monarcas, mediante mensajeros enviados a la corte, que otorgasen a vecinos de la ciudad las codiciadas escribanías reales, la mayoría de los cuales ya eran escribanos del número ${ }^{46}$.

En 1500 el concejo ordenó que todos los escribanos reales mostrasen sus títulos acreditativos en el ayuntamiento, «por quanto se dize que algunas personas vsan del ofiçio de escriuano del rey en esta çibdad syn thener titulo ni liçençia para ello» ${ }^{47}$.

Dentro de estas escribanías reales se encontraban las relacionadas con la recaudación de rentas reales y las vinculadas a la justicia. Por lo que se refiere a las primeras, existían varias escribanías: la de los diezmos y aduanas de Aragón, la de la Aduana de la ciudad de Murcia y la escribanía mayor de rentas del obispado de Cartagena. Entre las segundas, se encontraban las tres escribanías del juzgado de la ciudad de Murcia.

\section{a) Escribanía de los diezmos y aduanas de Aragón}

En el comienzo del reinado de los Reyes Católicos se produjeron una serie de tensiones entre la monarquía y el concejo murciano, al iniciar aquélla un proceso de recuperación del control de las escribanías. En 1479 la Corona recobró el nombramiento de escribano de los diezmos y aduanas de Aragón en contra de la ciudad, que hasta entonces se había encargado de tales nombramientos, y nueve años después hizo lo mismo con las tres escribanías del juzgado de la ciudad ${ }^{48}$. Sin embargo, una vez nombrados por los monarcas, debían prestar el acostumbrado juramento ante el concejo. El principal cometido del escribano de los diezmos de Aragón era otorgar albalaes firmados a los mercaderes que se dirigían a ese reino, en los que se daba fe de los derechos aduaneros pagados por las mercancías que transportaban. Hasta esa fecha correspondió, de forma incontestada, al concejo de Murcia

45 1488-IX-16, Valladolid, C.R. 1484-1495, fol. 14 v (Pedro López); 1488-IX-16, Valladolid, C.R. 14841495, fols. 14 r-v (Diego Riquelme); 1489-VII-14, Real sobre Baza, C.R. 1484-1495, fols. 29 v 30 r (Bartolomé Coque); 1490-III-13, Sevilla, C.R. 1484-1495, fols. 38 r-v (Rodríguez de Bustamante, Sevillón, Romi, Palazol, Belzunce, Pina y Sánchez de las Doncellas); 1495-VII-27, Burgos, C.R. 1484-1495, fol. 170 v (Juan Yáñez); A.C. 1497, 26-V-1498, fol. 106 r (Juan de Medina) y 1503-I-13, Madrid, C.R. 1494-1505, fols. 197 v 198 r (Juan Fernández de Pineda).

46 Juan de la Cueva y Fernando del Castillo, A.C. 1491, 2-XI-1491, fols. 55 v 57 r; Juan Yáñez y Alonso de Paloma-res, A.C. 1493, 14-I-1494, fols. 69 r 71 r; Francisco Pérez Beltrán, A.C. 1495, 9-IV-1496, fol. 153 r; Martín Lorenzo, Alonso Bernad de Palomeque, Juan Piñero, Diego López y Rodrigo Pérez, A.C. 1501, 9-IV-1502, fol. 157 v y 23-IV-1502, fol. 164 v. Conocemos únicamente la respuesta real a la petición sobre Juan Yáñez y Alonso de Palomares. Les fueron concedidas aunque debían ir a examinarse a la Corte, A.C. 1493, 15-III-1494, fols. $90 \mathrm{r}-\mathrm{v}$.

47 A.C. 1500, 12-IX-1500, fol. 45 r. No consta que alguno lo presentara, por lo que no podemos cuantificar los escribanos reales existentes en la ciudad de Murcia.

48 RODRÍGUEZ LLOPIS, MIGUEL: Ob. cit., pág. 13. Diego López Pacheco, marqués de Villena, conservó hasta 1475, por juro de heredad, dicha escribanía, pág. 14, nota 26 y nota 25. 
la provisión y nombramiento de dicho oficio entre alguno de los escribanos reales vecinos de la ciudad. En 1479, sustituyendo a Lope Núñez de Lorca, el concejo nombraba a su hermano Pedro Núñez de Lorca; sin embargo, un año después, los reyes concedían dicha escribanía a un tal Rodrigo de Herrera, nombramiento rechazado por el concejo alegando que pertenecía a la ciudad proveer de este oficio desde tiempo inmemorial ${ }^{49}$.

Ignoramos cuando el Licenciado Alvaro de Santesteban, regidor de Murcia y corregidor en varias ciudades durante esta época, consiguió esta escribanía. En 1495 declara que, desde hacía 7 años, tenía nombrado como fiel en su lugar a Alonso Sánchez de las Doncellas, vecino de Murcia, pero que, desde esa fecha, no había recibido de éste los emolumentos que le correspondían ${ }^{50}$. Por este motivo Sánchez de las Doncellas fue privado de su fieldad.

Sin embargo, meses después comenzaba una campaña de acoso contra el fiel nombrado por el titular de la escribanía, acusándole de carecer del título de escribano real, indispensable para el ejercicio del mismo ${ }^{51}$. Diego Ruíz, que también desempeñaba la escribanía de la Aduana de la ciudad de Murcia como fiel del regidor Sancho de Arróniz, presentó la documentación que le facultaba para el ejercicio de la escribanía de los diezmos de Aragón: un poder del Licenciado de Santesteban nombrándole sustituto suyo en la escribanía, con el mismo sueldo y derechos que percibía el anterior, Alonso Sánchez de las Doncellas (Jérez de la Frontera, 21-VIII-1495) y otro de Sancho de Arróniz autorizándole a usar de su oficio de escribano y tenente de la aduana de la ciudad (Murcia, 9-IX-1495). No obstante, el corregidor le prohibió ejercer este oficio pues, a pesar de todos los poderes presentados, Diego Ruíz no había demostrado ser escribano real ni del número, condición exigida para poder desempeñar dicha escribanía ${ }^{52}$.

Cuando poco después el regidor Sancho de Arróniz mostró un poder de Alvaro de Santesteban autorizándole a nombrar a un fiel que ejerciese por él el oficio, el concejo se limitó a pedirle que nombrase a uno que fuese escribano real o del número ${ }^{53}$. Al parecer fue nombrado de nuevo Sánchez de las Doncellas, pues en 1499, al arrendar éste la renta de los Diezmos de Aragón (lo que le imposibilitaba ejercer la escribanía), el concejo nombró como sustituto suyo a Diego Mateo, que también era fiel del escribano de la Aduana ${ }^{54}$.

Alonso Sánchez de las Doncellas es un personaje que aparece con cierta frecuencia en la documentación. Ignoramos casi todo lo relacionado con su vida familiar; únicamente que en 1498 estaba casado y que se hallaba emparentado de alguna forma con la influyente familia de los Riquelme. Aparte de sus obligaciones como escribano real (desde 1490) y como fiel de la escribanía de los diezmos de Aragón, sus intereses económicos se relacionaban, sobre todo, con el abastecimiento de pescado del Mar Menor a la ciudad

49 A.C. 1479 , 13-XI-1479, fol. 100 v y 16-XI-1479, fols. 109 v 110 r; A.C. 1480, 18-VII-1480, fols. $17 \mathrm{r}-\mathrm{v}$.

50 1495-III-28, Madrid, AGS, RGS, fol. 484.

51 A.C. $1495,19-\mathrm{IX}-1495$, fols. 36 v $37 \mathrm{r}$.

52 A.C. $1495,3-\mathrm{X}-1495$, fols. 39 v 42 r.

53 A.C. $1495,24-\mathrm{X}-1495$, fol. 57 v.

54 «para que por el dicho Liçençiado lo vse y administre, para lo qual le dieron poder e mandaron que acuda al dicho Liçençiado con el mismo ynterese que el dicho Alonso Sanchez le acudia», A.C. 1498, 22-VI1499 , fols. $136 \mathrm{v} 137 \mathrm{r}$. 
de Murcia y el arrendamiento de rentas reales y concejiles. En 1491, 1492, 1493, 1494, 1496, 1498, 1501 y 1502, asociado con el arráez Juan de Burgos, arma un «boliche largo» para dedicarse a la pesca en el Mar Menor ${ }^{55}$. En 1495 pujó infructuosamente para hacerse cargo, junto a Gonzalo Ruiz, del abastecimiento de pescado salado a la ciudad ${ }^{56}$ y en 1502 , en compañía de Pedro Fernández y Diego Mateo, arrendó la renta de la Sisa, la principal fuente de ingresos del concejo, volviendo a pujar por ella sin éxito dos años después ${ }^{57}$. Como acabamos de ver, de 1497 a 1501 fue fiador primero y después arrendador de los Diezmos de Aragón en los puertos de Almansa y Yecla y Murcia y recaudador en este último lugar de este impuesto aduanero a partir de 1502 en nombre de Martín de Córdoba y Diego de Alarcón ${ }^{58}$.

En su faceta de recaudador de rentas se hizo extraordinariamente impopular. Ya en 1497 sufrió una agresión por parte de un tal Sebastián, del que desconocemos su filiación y los motivos que le llevaron a herirle de una cuchillada. Su parentesco con los Riquelme induciría a pensar al corregidor que se podrían producir disturbios en la ciudad, por lo que estuvo tres meses en la cárcel ${ }^{59}$. En 1501 los vecinos se quejaban de que les cobraba más derechos de diezmo de los que debía percibir, situación que se había agravado de tal manera que cinco años después el concejo le prohibía de forma terminante, so pena de destierro y de $10.00 \mathrm{mrs}$, inmiscuirse en el cobro de las rentas de alcabalas y almojarifazgo, pues, «como mal vezino ynventa ynpusiçiones e derechos nuevos e otras cosas contra los dichos vezinos y ynpone a los almoxarifes e alcaualeros e otras personas que tienen cargo de cobrar las rentas de sus altezas que las piden e lleuen, e el se encarga por ellos de las cobrar, e las cobra e pide e por todas las formas e maneras que puede fatyga a los vezinos de la dicha çibdad» ${ }^{60}$.

55 A.C. 1491, 2-VII-1491, fol. 9 r; A.C. 1492, 15-IX-1492, fol. 75 v; A.C. 1493, 2-VII-1493, fol. 6 v y 16-VII-1493, fol. 10 r; A.C. 1494, 30-VIII-1494, fol. 43 r, 6-IX-1494, fol. 45 v, 15-XI-1494, fol. 81 r; A.C. 1496, 29-VI-1496, fols. 8 r-v; A.C. 1498, 2-X-1498, fol. 55 r, 16-X-1498, fols. 60 v 61 r, 3-XI-1498, fol. 69 v, 12-I-1499, fol. 93 v; A.C. 1501, 25-VIII-1501, fols. 36 r-v; A.C. 1502, 15-X-1502, fols. 84 v 85 r y A.C. 1503 , 5-IX-1503, fols. $57 \mathrm{r}-\mathrm{v}$.

56 A.C. $1495,10-\mathrm{X}-1495$, fols. 47 v 48 r.

57 Ofreció 170.000 mrs, A.C. 1504, 24-VI-1504, fol. 4 v.

58 1499-V-27, Madrid, C.R. 1494-1505, fols. 53 r-v; 1499-V-28, Torrijos, C.R. 1494-1505, fols. 51 r 52 r; A.C. 1498, 18-VI-1499, fols. 135 v 136 r y 22-VI-1499, fols. 136 v 137 r; A.C. 1499, 3-III-1500, fol. 129 r y A.C. $1500,15-I X-1500$, fol. 48 r y 2-III-1501, fol. 140 v; 1502-XII-13, Madrid, C.R. 1494-1505, fols. 176 v 177 r y A.C. $1502,10-\mathrm{I}-1503$, fol. 149 r.

59 «el dicho Sabastian diz que dio vna cuchillada al dicho Alfonso Sanchez, e que Alfonso Riquelme, su tio, por ser el dicho Alfonso Sanchez su amigo, ovo de yr a verle por saber el caso como avia pasado, e que le dixo que sy alguna cosa ouiere menester que ge lo daria, e que pues a esta cabsa algunas personas de esa dicha çibdad maliçiosamente ynformaron a vos, el dicho nuestro corregidor, que el dicho Alfonso Riquelme andaba alborotando la dicha çibdad para dar favor e ayuda al dicho Alfonso Sanchez para que bengase la dicha cochillada, a la qual cabsa diz que vos, mostrandovos contra el muy odioso e sospechoso e faborable a la otra parte, le prendistes e tovistes preso tres meses», 1499-I-17, Ocaña, AGS, RGS, fol. 43. La carta real ordenando al corregidor que tomase dos acompañados en esta causa fue conseguida por el regidor Pedro Riquelme, hecho que vendría a corroborar su parentesco con esta familia.

60 A.C. 1501, 16-XI-1501, fol. 87 r. El concejo le calificó de «persona que tiene enemistad a su patria», A.C. 1506 , 14-VII-1506, fol. 14 v y 29-XII-1506, fol. 97 r. 
Sánchez de las Doncellas desaparece de la documentación consultada a partir de 1506 y no volvemos a tener noticias de este oficio hasta 1515, fecha en la que el regidor Diego de Lara presentó una carta real concediéndole la escribanía de los diezmos de Aragón, en lugar y por renuncia de su padre, el Licenciado de Santesteban ${ }^{61}$.

\section{b) Escribanía y fialdad de la Aduana de Murcia}

Muy relacionada con la anterior escribanía. De hecho, ambos oficios se ejercían en el mismo edificio, las casas de las Aduanas de la ciudad de Murcia; eran desempeñadas casi siempre por la misma persona, un fiel nombrado por los titulares de ambas escribanías, dos regidores del concejo murciano. Para completar los puntos en común habría que añadir que existe una completa disociación entre los ostentadores de las dos escribanías, miembros influyentes del patriciado murciano con vínculos muy estrechos con la monarquía (ambos fueron corregidores), y la persona que, como fiel, ejerce realmente el oficio, a sueldo de los anteriores.

El escribano y fiel de las Aduanas, como se le llamaba oficialmente, debía cobrar una serie de derechos por expedir los albaláes que certificaban que las mercancías habían pasado por la Aduana de la ciudad y pagado las tasas correspondientes en concepto de almojarifazgo u otros derechos mercantiles ${ }^{62}$. Además, debía notificar al procurador síndico de la ciudad los agravios perpetrados por los arrendadores reales a los vecinos de Murcia, sobre todo los ocasionados por el incumplimiento por parte de aquellos de los privilegios, usos y costumbres de la ciudad.

En 1484 los reyes proveyeron de esta escribanía a Sancho de Arróniz en lugar y por renuncia del regidor Juan de Cascales. El nuevo titular era miembro de una de las familias más poderosas de la ciudad, contino real, corregidor en Medina del Campo en una ocasión y poco después regidor ${ }^{63}$. Un año después tuvo que vencer la resistencia del concejo, que se negaba a aceptar a Sánchez de las Doncellas como casero y fiel de las Aduanas en su

61 A.C. 1515, 21-VIII-1515, fol. 36 r. La carta real: 1515-VIII-1, Aranda de Duero, C.R. 1515-1513, fols. 26 r-v.

62 En 1484 se fijaron tales derechos: cobraría 2 mrs. por redactar manifiestos y albaláes comunes; 18 mrs. por albalá de casa movida, por moro cautivo, por cabaña o caballo cuando viniese a pastar o regresase a su tierra; 1 mri. por pieza de paño «merchaniego». Además, del impuesto de almojarifazgo, que gravaba con un 5 por ciento todas las mercancías que se traían a venderse a la ciudad y con un 2'5 por ciento las que se volviesen a sacar, el arrendador cobraba las dos terceras partes y el fiel un tercio, A.C. 1484, 13-XI-1484, fols. 57 r 58 r. En 1492 Alonso Sánchez de las Doncellas, escribano y fiel de la Aduana de Murcia, se quejó a los reyes de que los arrendadores de los Diezmos y Aduanas de los obispados de Cuenca y Cartagena no le permitían cobrar los $2 \mathrm{mrs}$ que hasta entonces percibía «por registrar e dar el dicho alvala por cada camino por todas e quantas e qualesquier mercaderias que aquel camino truxere», ordenando los monarcas que fuese respetada tal condición, recogida en el cuaderno de dicha renta, 1492-XI-13, Olmedo, C.R. 1494-1505, fols. 31 v 32 r. En 1504 el escribano y fiel de la Aduana se quejó a los reyes que los arrendadores del almojarifazgo no tramitaban dicho im-puesto en el Aduana, disponiendo éstos que lo hicieran, 1504-IV-30, Medina del Campo, Legajo $4.282 \mathrm{n}^{\circ} 29$ y C.R. 1494-1505, fols. 288 v 289 r, A.C. 1503, 1-VI-1504, fol. 163 r.

63 1484-XII-22, Sevilla, C.R. 1478-1488, fols. 143 v 144 v. Ignoramos cómo consiguió Cascales la escribanía. Un mes antes el concejo tildaba a éste de «fiel que se dixo de las Aduanas de esta çibdad por el rey e reyna nuestros señores» y nombraba como fiel a Pedro Mellado, A.C. 1484, 13-XI-1484, fols. 57 r 58 r. 
lugar y 10 años más tarde, a instancias del concejo, tuvo que volver a presentar «la carta de merçed que tiene de la merçed de las aduanas» ${ }^{64}$. En esta última época había nombrado como fiel a Diego Ruiz, cuestionado por Sánchez de las Doncellas, como hemos visto más arriba.

Sancho de Arróniz mantuvo la titularidad de la escribanía hasta su muerte, acaecida en 1498. En junio de ese año era presentada una carta real concediendo a su hijo, Luis de Arróniz, dicho oficio ${ }^{65}$. Tampoco la desempeñaría personalmente sino que se nombró para tal fin a Diego Mateo. Luis de Arróniz, que no era vecino de la ciudad sino que residía permanentemente en Toledo, volvió a nombrar otro fiel en 1503. En esta ocasión Pedro Martínez, también vecino de Toledo, presentó al concejo una carta de Arróniz facultándole el ejercicio de dicho oficio en su lugar. Al principio, el concejo se negó a aceptarle como tal, pues se tenía la completa certeza de que había arrendado el oficio por $15.000 \mathrm{mrs}$ «e que era ofiçio que no se podia arrendar, porque el fiel no auia de tener ninguna pena syno dezir verdad». Aunque el pesquisidor estaba realmente interesado en rechazar al sustituto asegurando que el arrendamiento perjudicaba a las rentas reales y a los vecinos, pues Martínez «por auer la dicha renta lleuaria mas de lo que deuia» meses después tuvo que aceptarle como fiel ${ }^{66}$.

\section{c) Escribanía mayor de rentas del obispado de Cartagena}

Estaba en manos de Alfonso Álvarez de Toledo, señor de Cervera, y, por lo menos desde 1495 ejercía dicho oficio en su nombre el jurado Alonso de Auñón, también escribano del número de la ciudad de Murcia ${ }^{67}$. La misión principal de este escribano era la de efectuar la subasta de las rentas reales que no se arrendaban en la corte ante los contadores reales, dirigía los arrendamientos «por menudo» y enviaba a la Contaduría relaciones del valor de cada renta. Los escribanos de rentas cobraban por arancel un $1 \%$ del importe de todas las rentas que se arrendasen con su intervención ${ }^{68}$.

En 1499 renunció a su escribanía del número en favor de Juan Piñero y en 1500 se presentaba en el concejo una carta real, aceptando los monarcas a Auñón como sustituto

64 A.C. 1485 , 9-VII-1485, fol. 10 r y A.C. 1495 , 10-XI-1495, fol. 70 v.

65 1498-V-13, Toledo, C.R. 1494-1505, fols. 42 r-v. Concedió un poder a su madre, Juana Pacheco, autorizando a ella o a quien tuviese su poder a tomar posesión de la escribanía en su nombre. Garci Gutiérrez de Madrid presentó un poder de ésta a su favor, tomó posesión de la misma, A.C. 1497, 9-VI-1498, fols. 110 v $111 \mathrm{r}$.

66 A.C. 1502, 2-III-1503, fols. 192 r 193 r, 4-III-1503, fols. 195 r 196 r y 3-VI-1503, fols. 252 v 253 r. Garci Gutiérrez de Madrid presentó un poder de Luis de Arróniz autorizándole a «poner qualquier fiel o fieles en la dicha escriuania», nombrando a continuación a Pedro Martínez. En 1510 Arróniz renunció la escribanía en Ximen Pérez Corella Fajardo, quien nombró como teniente al mismo Pedro Martínez, 1510-X-26, Madrid, C.R. 1505-1514, fols. 56 r-v y A.C. 1510, 10-XII-1510, fols. 90 v 91 r.

67 A.C. 1494 , 3-I-1495, fol. 99 v.

68 «eran cargos nombrados por el rey directamente y solían recaer en personajes a los que se deseaba favorecer económicamente, pues muchos actuaban por medio de lugartenientes», LADERO QUESADA, MIGUEL ÁNGEL: La Hacienda Real de Castilla en el siglo XV, Universidad de la Laguna, Secretariado de Publicaciones, Sevilla 1973, pág. 24. 
de Alfonso Álvarez de Toledo en la escribanía mayor de las rentas del obispado de Cartagena y reino de Murcia ${ }^{69}$.

\section{d) Escribanías del juzgado de la ciudad de Murcia}

Dentro del grupo de escribanías proveídas por la monarquía se encontraban las tres escribanías del juzgado de la ciudad de Murcia. Hasta 1488, igual que las demás escribanías reales analizadas, se hallaban vinculadas a miembros de la aristocracia castellana y de la nobleza regional, llegándose al extremo de que algunos de los que las ocupaban consiguieron convertirlas en hereditarias, aunque no lograron integrarlas en sus patrimonios. En el último cuarto del siglo XV las tres escribanías estaban en poder de la familia Escarramad (que ocupaba este oficio desde 1393) y de la familia Abellán, alguno de cuyos miembros fueron regidores y jurados de la ciudad de Murcia.

En 1488 eran «propietarios» de las tres escribanías Francisco Abellán y Francisco Escarramad. Por orden real, debían renunciar a ellas «en poder de personas abiles», las cuales serían confirmadas posteriormente por los monarcas. Nombraron a los escribanos del número Pedro López, Diego Riquelme y Antón Rodríguez de Alcaraz y pidieron al concejo que declarase que «los dichos nonbrados heran tales personas e de buena fama», información que se añadiría a la renuncia para que fuese confirmada por el Consejo Real ${ }^{70}$. En noviembre de ese mismo año se presentaban las tres cartas reales confirmando la renuncia y aceptando los tres nombramientos, por lo que los nuevos escribanos del juzgado prestaron juramento ese mismo día ${ }^{71}$. A partir de entonces, los tres oficios experimentaron una serie de vicisitudes por lo que se refiere a la titularidad de las mismas. En total se produjeron 12 cambios, 3 por nombramiento real $(25 \%)$ y 9 por renuncia del anterior escribano $(75 \%)$.

Cabría destacar que los primeros poseedores de estas tres escribanías, por motivos que no sabemos, las desempeñaron muy poco tiempo, 4 años el que más. Pedro López, que la renunció en 1490, y Diego Riquelme, que lo hizo en 1491, estuvieron ejerciendo sus escribanías del número hasta 1513 y 1507 respectivamente. Ello significaría que la renuncia no estuvo motivada por problemas de salud o incapacidad para ejercer el oficio por los renunciantes sino que muy posiblemente fueron compradas por los nuevos titulares.

Por lo que se refiere a la primera escribanía, la ocupada por Antón Rodríguez, éste estuvo desempeñando su oficio hasta enero de 1492, fecha en que la renunció en Bartolomé Coque, escribano del número. El concejo le autorizó a ejercerla, dándole tres meses de

69 En la carta se explicaban las circunstancias del nombramiento: «por nuestra carta enbiamos mandar a todas e qualesquier personas que toviesen ofiçios de nos en nuestra corte que, fasta noventa dias primeros siguientes, viniesen personalmente a seruir sus ofiçios e los que touiesen justo ynpedimento e los oviesen de seruir por sostitutos los nonbrasen ante nos dentro de çierto termino». Una vez que se recibió en el Consejo Real la información exigida, probando que su sustituto era hábil y suficiente para el desempeño de dicho oficio, se le aceptaba como su lugarteniente, 1500-IX-18, Granada, C.R. 1494-1505, fol. 90 v y A.C. 1500, 10-X-1500, fol. $59 \mathrm{v}$.

70 RODRÍGUEZ LLOPIS, MIGUEL: Ob. cit., pág. 14, nota 24; A.C. 1488, 16-VIII-1488, fols. 27 r-v.

71 A.C. 1488, 4-XI-1488, fols. 81 v 82 v; 1488-IX-16, Valladolid, C.R. 1484-1495, fols. 14 r 14 v. 
CUADRO N ${ }^{\circ} 2$

Escribanias del juzgado de la ciudad de Murcia (1488-1514)

\begin{tabular}{|c|c|c|c|}
\hline & NOMBRE & MODO DE ACCESO & FECHA \\
\hline \multirow[t]{5}{*}{$1^{\mathrm{a}}$} & Antón Rodríguez de Alcaraz & Renuncia del anterior & $1488-1492$ \\
\hline & Pedro Abellán & Nombramiento real & $1492-1493$ \\
\hline & Miguel de Contreras & Renuncia del anterior & $1493-1497$ \\
\hline & Antón Sevillón o Sevillano & Renuncia del anterior & $1497-1506$ \\
\hline & Francisco de Valcárcel & Renuncia del anterior & $1506-1514$ \\
\hline \multirow[t]{6}{*}{$2^{\mathrm{a}}$} & Pedro López & Renuncia del anterior & $1488-1490$ \\
\hline & Francisco de Ayerbe & Renuncia del anterior & $1490-1496$ \\
\hline & Alonso Rodríguez de Almela & Nombramiento real & $1496-1497$ \\
\hline & Diego de Soto & Renuncia del anterior & 1497 \\
\hline & Fernán Pérez de Monzón & Renuncia del anterior & $1498-1503$ \\
\hline & Francisco de la Plaza & Renuncia del anterior & $1503-$ \\
\hline \multirow[t]{4}{*}{$3^{\mathrm{a}}$} & Diego Riquelme & Renuncia del anterior & $1488-1491$ \\
\hline & Juan Jiménez de Medrano & Renuncia del anterior & $1491-1500$ \\
\hline & Salvador de Villagómez & Renuncia del anterior & $1500-1504$ \\
\hline & Juan de Medina & Nombramiento real & $1505-$ \\
\hline
\end{tabular}

plazo para traer la provisión real confirmándole en el oficio ${ }^{72}$. Sin embargo, no fue éste el designado por los reyes, sino el Bachiller Pedro Abellán, que en noviembre presentaba la oportuna carta real y prestó el juramento acostumbrado y se le hizo entrega de la documentación del anterior escribano ${ }^{73}$.

Desempeñó poco tiempo el oficio pues en febrero de 1493 renunciaba en Miguel de Contreras, escribano del número ${ }^{74} .4$ años más tarde, éste renunciaba a su vez en Antón

72 A.C. 1491, 28-I-1492, fols. 108 v 109 r. En mayo, algunos regidores pidieron al corregidor que suspendiera a Coque «por çierto yerro que fizo» (del que no hay más noticias), además de que carecía del poder necesario para ello. El representante real se limitó a pedir al concejo que se nombrase otro escribano que acompañase a Coque en el ejercicio de la escribanía, 19-V-1492, fol. $141 \mathrm{r}$.

73 A.C. 1492, 14-XI-1492, fols. 131 v 132 v. En la carta real se menciona que Antón Rodríguez había muerto, 1492-X-6, Zaragoza, C.R. 1484-1495, fols. 105 r-v.

74 1493-II-22, Barcelona, C.R. 1484-1495, fols. 122 v 123 r. 
Sevillano, también escribano del número ${ }^{75}$; quien, a su vez, renunciaba en 1506 en Francisco de Valcárcel, escribano del número. Este haría lo mismo en 1514 con Diego Pellicer ${ }^{76}$.

La segunda escribanía la estuvo ejerciendo Pedro López hasta 1490, cuando la renunció en Francisco de Ayerbe ${ }^{77}$, quien en 1492 pidió autorización al concejo para ausentarse de la ciudad y nombrar sustituto. Quizá temía por su integridad física pues se hallaba enemistado, por causas que desconocemos, con Juan de Montealegre, comendador de Aledo y con su hermano, el provisor eclesiástico Pedro Ruíz de Montealegre, rivales temibles que no dudaban, al menos el clérigo, en enfrentarse con garantías de éxito al corregidor Juan Pérez de Barradas, lo que hizo por estas mismas fechas, provocando disturbios urbanos serios ${ }^{78}$. Buscando justicia y seguridad personal, y, quizá, huir de los acreedores que le acosaban, nuestro escribano marchó a Roma, donde sin duda expondría su alegato contra el provisor en la curia vaticana. Y es que sus problemas no se reducían a sus malas relaciones con los Montealegre; por esta misma época demandaba criminalmente ante un juez comisario real a su esposa, Juana Navarra, y al Bachiller Francisco Blasco, acusados de adulterio. Aunque se dictó sentencia en favor de nuestro escribano, por la que las personas y bienes de los condenados pasaban al marido, y fue confirmada por los alcaldes de casa y corte, no le fue nada fácil conservar los bienes que le habían sido entregados. En junio de 1492 su mujer y el Bachiller Blasco habían huído de la ciudad y no habían sido ejecutadas las sentencias y varios meses después el juez de residencia devolvía sus bienes a Juana Navarra e incautaba toda la documentación del proceso a Ayerbe, entregándola a ciertos escribanos de la ciudad que se negaban a devolvérsela. Los gastos del pleito le habían endeudado completamente; sus deudas contraídas con ciertas personas acomodadas de la ciudad ascendían a $37.880 \mathrm{mrs}$, encontrándose «muy alcançado, tanto e por tal manera que syn grand daño de su fazienda no podria pagar los dichos maravedis a los plazos a que esta obligado ni parte alguna de ellas» ${ }^{79}$. En enero de 1496 parece ser que había muerto en Roma, pues Alonso Rodríguez de Almela presentaba una cédula de la

75 1497-XII-20, Alcalá de Henares, AGS, RGS, fol. 10.

76 A.C. 1505, 3-I-1506, fols. 97 v 98 r. La carta real: 1505-XII-17, Salamanca, C.R. 1494-1505, fols. 275 r-v y A.C. $1513,18-$ III-1514, fol. 130 r.

77 A.C. 1490, 31-VIII-1490, fol. 23 v. La carta real: 1490-V-20, Alcalá la Real, C.R. 1484-1495, fols. 52 v $53 \mathrm{v}$.

78 1492-IV-?, Córdoba, AGS, RGS, fol. 44: se concede un seguro a Francisco de Ayerbe contra los mencionados: «el se teme e reçela que por odio e enemistad e malquerençia que con el han e tienen Juan de Montalegre, comendador de Aledo e Pero Ruyz de Montalegre, su hermano, e sus parientes e criados e otras personas, asy vezinos de la dicha çibdad de Murçia como de fuera de ella, que el entiende de nonbrar e declarar ante vos las dichas justiçias, le heriran o mataran o lisiaran o prenderan a el e a sus hermanos, omes e criados e le tomaran e ocuparan sus bienes o alguna parte de ellos». Esta alteración del orden público mencionada se produjo cuando el provisor se negó a cumplir el destierro impuesto por el corregidor, asegurando que no saldría de la ciudad pacíficamente, por lo que el representante real recurrió a todos los vecinos armados. Al final abandonó Murcia, no sin antes poner en entredicho la misma y excomulgar al representante real y a sus oficiales. Toda su conducta delictiva (secuestro de un fraile franciscano por tropas armadas a su servicio entre otros hechos) se encuentra descrita en una carta real encargando al pesquisidor Aguilera que investigara el asunto, 14-V-1492, Santa Fe, AGS, RGS, fol. 636.

79 Los reyes ordenaron a sus acreedores que esperasen 6 meses para cobrar la deuda, 1493-III-20, Barcelona, AGS, RGS, fol. 7. Todo este calvario judicial y personal se halla en 1492-IV-, Córdoba, AGS, RGS, fol. 340; 1492-VI-4, Córdoba, AGS, RGS, fol. 108; 1493-III-19, Barcelona, AGS, RGS, fols. 272 y 274. 
reina prometiéndole «proueer del primero ofiçio de escriuania del juzgado que vacare en la dicha çibdad» ${ }^{80}$.

Un año después, inexplicablemente, renunciaba la escribanía del juzgado en favor de Diego de Soto, mozo de cámara del rey, el cual no llegó a tomar posesión del oficio, pues meses más tarde renunciaba en beneficio de Fernán Pérez de Monzón, en aquel momento escribano público de León. El nuevo escribano no era un desconocido para el concejo murciano, pues había sido nombrado escribano del número de Murcia en abril de 1491. Muy posiblemente la rapidez de estos cambios en la titularidad de la escribanía y el que sus beneficiarios no residieran en la ciudad en el momento de conseguir el oficio supondrían que la renuncia no habría sido desinteresada y que el nuevo escribano la habría comprado al renunciante ${ }^{81}$.

Aunque prestó juramento en enero de 1498, no comenzó realmente a ejercer el oficio hasta junio de ese mismo año, fecha que el concejo le dió de plazo para que regresara a León y trajera a su esposa y bienes. Mientras tanto, se le permitió nombrar un sustituto en su lugar ${ }^{82}$. En 1503 renunciaba en Francisco de la Plaza, que también era escribano de la Inquisición ${ }^{83}$.

La tercera escribanía estuvo en manos de Diego Riquelme hasta 1491, año en que la renunció en favor de Juan Jiménez de Medrano, escribano del número ${ }^{84}$, quien en 1500 la renunciaba a su vez en Salvador de Villagómez ${ }^{85}$, el cual la ejerció poco tiempo, pues ya en julio de 1501 había huído de la ciudad acusado de un asesinato ${ }^{86}$.

Hasta 1504 no volvemos a tener más noticias. En octubre de ese año Antonio Hurtado consiguió esta escribanía. Su padre y su tío ya eran jurados y su hermano Diego lograría en

80 Fue aceptado por el concejo, aunque se le pidió que probase de forma fehaciente que el anterior titular había falleci-do, A.C. 1495, 19-I-1496, fols. 113 v 114 r. Cosa que hizo algunos meses más tarde, A.C. 1495, 6-IV-1496, fols. 151 v 152 v. En la carta real se le concedía dicha escribanía «en logar y por bacaçion de Françisco Yerves, nuestro escriuano de cadira que fue de la dicha çibdad, por quanto el es fallesçido y pasado de esta presente vida», 1496-III-20, Tortosa, C.R. 1494-1505, fols. 13 v 14 r.

81 La carta real, que fue presentada en el concejo en septiembre de 1497 por el escribano del número Francisco de Palazol, no explica las razones ni las circunstancias de estos cambios en la titularidad de la escribanía. En ella se repite las mismas fórmulas empleadas en los otros nombramientos. Se limita a señalar que: «por hazer bien e merçed a vos Fernand Perez de Monçon, escriuano publico e vezino de la çibdad de Leon, acatando vuestra sufiçiençia e abilidad e buena conçiençia e algunos buenos seruiçios que nos avedes fecho e fazedes de cada dia, tenemos por bien y es nuestra merçed que agora e de aqui adelante para en toda vuestra vida seades nuestro escriuano vno de los tres del juzgado de la cadira de la justiçia de la çibdad de Murçia en lugar de Diego de Soto, moço de camara de mi el rey, nuestro escriuano que fue del dicho ofiçio e a quien nos hezimos merçed, por quanto el dicho Diego de Soto renuzçio en nuestras manos el dicho ofiçio en vuestro fauor e nos suplico e pidio por merçed por su petiçion e renuzçiaçion firmada de su nonbre e sygnada de escriuano publico que vos proveyesemos e fiziesemos merçed del dicho ofiçio de escriuania», A.C. 1497, 23-IX-1497, fol. 43 v: 1497-VII-21, Me-dina del Campo, C.R. 1494-1505, fols. 17 r-v. La renuncia de Rodríguez de Almela en favor de Diego de Soto se encuentra en 1497-V-?, Burgos, AGS, RGS, fol. 152. Sobre las vicisitudes personales de Pérez de Monzón, véase nota 18.

82 A.C. $1497,2-\mathrm{I}-1498$, fols. 67 v 68 r.

83 A.C. $1503,17-X-1503$, fols. 74 r-v. La carta real: 1503-IX-20, Segovia, fols. 206 r-v.

84 1491-I-15, Sevilla, C.R. 1484-1495, fol. 74 r.

85 A.C. 1499, 18-II-1500, fol. 121 r. La carta real: 1500-II-8, Sevilla, C.R. 1494-1505, fol. 65 r. Era yerno de Francisco Pedriñán, cuya riqueza patrimonial era considerable. Fue fiador del pesquisidor Diego Romaní, alcalde de la Huerta en 1502 y alférez en 1507.

$86 \mathrm{Su}$ suegro pidió que se nombrase un escribano que desempeñara el oficio en nombre de su yerno, A.C. 1501, 20-VII-1501, fol. 21 r. El concejo nombró a Juan de Tordesillas, 24-VII-1501, fol. 23 v. 
junio de 1505 la regiduría de Antón Saorín, vacante al haber sido acusado éste de asesinato, al igual que el titular de la escribanía. Francisco Pedriñán, suegro de Villagómez, lo mismo que la familia Saorín con el nuevo regidor Diego Hurtado, intentó que el concejo no le aceptase como escribano del juzgado, alegando que se había apelado la sentencia por la que su yerno había perdido el oficio ${ }^{87}$. Pero, al igual que la familia Saorín, tampoco tuvo éxito en su pretensión, y a comienzos de 1505 Juan de Medina, en quien había renunciado Antonio Hurtado, presentaba el nombramiento real y prestaba juramento ante el concejo ${ }^{88}$.

Las quejas contra la actuación de los escribanos del juzgado se repiten. El concejo murciano, consciente de la importancia de estos oficios en el ámbito judicial y político y como fuente saneada de rentas para la siempre necesitada hacienda municipal, pidió en alguna ocasión a los monarcas la concesión a la ciudad de estas tres escribanías «para ayuda a las neçesydades que tiene» ${ }^{89}$.

Por otra parte, algunas veces el concejo acusa a los escribanos del juzgado de exigir derechos superiores a los permitidos por la ley y de hallarse en connivencia con los corregidores, ayudando a éstos en los juicios de residencia. En 1515 un mensajero de la ciudad se quejó al rey de que, como los actos civiles y criminales tenían lugar ante los escribanos del juzgado y éstos entablaban amistad con el corregidor, cuando éste realizaba su residencia al finalizar su mandato, dichos escribanos le ayudaban todo lo que podían, por lo que solicitaban que la residencia se efectuase ante alguno de los escribanos del número de la ciudad ${ }^{90}$.

87 A.C. 1504, 26-X-1504, fols. 40 v 41 r. Pedriñán afirmaba que «agora a su notiçia hera venido que Antonio Hurtado avia traydo vna merçed de sus altezas del ofiçio del escriuania del dicho Villagomez, su yerno». Aunque no consta que Hur-tado presentara ninguna provisión en el concejo, en noviembre firmó una carta de obligación con Juan de Medina, en quien había renunciado la escribanía que le habían concedido los reyes, garantizándole la pacífica posesión del oficio, obligándose Hurtado a pagarle 160 castellanos de oro en caso de ser despojado de él, Murcia, 14-XI-1504, Legajo 4.290 nº 59. Según parece, esta familia tenía pocos escrúpulos, pues en 1506 el concejo acusaba a un hermano del regidor Diego Hurtado de salteador de caminos, A.C. 1506, 27-X-1506, fols. 61 r 62 v.

88 A.C. 1504, 22-II-1505, fols. 121 r-v. En la carta real no se menciona esta renuncia, únicamente se dice que el anterior escribano, Villagómez, «fue priuado del dicho ofiçio porque mato malamente a Juan de la Parrilla e por ello fue condepnado a pena de muerte», 1505-I-31, Toro, C.R. 1494-1505, fol. 249 r, Apéndice Documental, IV.

89 A.C. $1490,31-$ VIII-1490, fol. 23 v.

90 «les favoreçen y ayudan e saluan todo lo que pueden y pasando la regidençia por ante ellos es en gran perjuizio de los vezinos de la dicha çibdad, que su alteza mande que la dicha regidençia no pase ante ninguno de los dichos tres escriua-nos de judgado syno ante vn escriuano de los deziocho del numero de la dicha çibdad», 27-I-1515, Legajo 4.279 n $^{\circ} 42$. Quejas sobre el cobro de derechos excesivos: A.C. 1497, 4-XI-1497, fols. 57 r-v y A.C. 1500, 18-VII-1500, fol. 23 r. En 1492, los escribanos del juzgado habían protestado ante el Consejo Real contra la intromisión, habitual, de los corregidores en su oficio, pues, según decían, aunque ante ellos debían pasar todos los «abtos» civiles y criminales que se sustanciasen ante la justicia, los representantes reales tomaban un escribano ante quien pasaban las causas criminales, arrendaban dicha escribanía o cobraban parte de sus derechos; y cuando dicho escribano era de fuera de la ciudad, al finalizar el mandato del corregidor que le había nombrado, se llevaba consigo los procesos «e no queda razon ni cuenta de ella»; los reyes ordenaron guardar una ordenanza que regulaba el tema, 1492-V-28, Córdoba, AGS, RGS, fol. 338, Apéndice Documental, I. En 1500, a petición del concejo, otra carta real prohibía a los corregidores apropiarse de los derechos que pertenecían a los escribanos del crimen, 1500-I-4, Sevilla, Legajo 4.272 n 104 y C.R. 1494-1505, fol. 66 r. En 1503 se acusó al anterior pesquisidor de haber arrendado una de las escribanías, A.C. 1502, 20-V-1503, fol. 245 v. 
Estos dos hechos y el que las escribanías no estuvieran controladas por el patriciado murciano, al menos en su provisión directa, hizo que el concejo se mostrase especialmente vigilante con los escribanos del juzgado.

Aparte de ésto, la problemática que suscitaban era similar a la ya tratada en las escribanías del número. Se denuncia con cierta frecuencia que las escribanías del juzgado, pese a las órdenes reales en sentido contrario, eran desempeñadas por sustitutos ${ }^{91}$. Otras veces el concejo se lamentaba de las ausencias de la ciudad por parte de los titulares de las escribanías. Así, en 1499 coincidió la ausencia de los tres escribanos de Murcia ${ }^{92}$.

Sobre algún escribano en concreto se acumulan las denuncias. Es el caso de Juan Yáñez, quien ejercía el oficio en lugar de Miguel de Contreras. Por motivos que ignoramos, parece contar con la animadversión del concejo murciano. En 1494 se le suspende dicha sustitución, pidiéndose al titular de la escribanía que viniese a ejercerla personalmente, pues, según se explicaba, Yáñez «ha fecho muchos yerros e cosas con el dicho ofiçio que tiene, que no guarda la fialidad que deue e daña a los vezinos e moradores de esta dicha çibdad e les es muy odioso» ${ }^{93}$.

En 1500 lo encontramos de nuevo ejerciendo la escribanía de las alcabalas y se le acusa de prevaricación, al haber cobrado injustamente a los vecinos que venían a igualar con el arrendador de dicho impuesto tasas excesivas ${ }^{94}$. Evidentemente no sufrió ningún tipo de castigo ni fue inhabilitado para desempeñar la escribanía, pues en 1503 seguía ejerciendo el oficio sin mayores problemas, aunque el concejo continuaba persiguiéndole inutilmente ${ }^{95}$.

91 En 1494 Juan Yáñez sustituía al titular de la escribanía, Miguel de Contreras, A.C. 1494, 8-XI-1494, fol. 75 r. En 1497 el concejo pedía al alcalde que mandase guardar la orden real que disponía que tales escribanías fueran ejercidas por los titulares, A.C. 1496, 25-II-1497, fol. 106 r. En 1499 Juan de Medina era denunciado por tener arrendada la escribanía del juzgado de Juan Jiménez de Medrano, A.C. 1499, 14-XII-1499, fol. 99 r. En 1512 se reprochaba a Francisco de Valcárcel que no desempeñase personalmente su oficio y empleara un sustituto, A.C. 1512, 30-X-1512, fols. 43 r-v.

92 Uno se encontraba en Jumilla, otro en Huesca y el otro se hallaba en paradero desconocido, pues «a fecho çiertos delitos e se a absentado de la çibdad», A.C. 1499, 17-XII-1499, fols. 99 v 100 r.

93 A.C. 1494, 4-X-1494, fols. 56 r-v, 4-XI-1494, fol. 72 v y 8-XI-1494, fol. 75 r. Dos años antes se le había acusado de blasfemo, cuando, esperando ser nombrado escribano del número, exclamó «pese a Dios» al otorgar el concejo dicho oficio a otra persona, A.C. 1492, 14-XI-1492, fol. 133 r. En 1512, otro escribano, Juan Piñero, sería acusado del mismo delito, pues «ovo renegado de muchos reniegos, los quales son graues de dezir, de Nuestra Señora y de su virginidad e de otros, e aquel fue denunçiado ante el juez pasado y como heran honbres que le temian sus formas e cabtelas no lo quisieron castigar, como ved que aquello hera notorio y publico, que en esta yglesia mayor estuuo con vna candela y desnudo por la Ynquisiçion, que a falta de Justiçia tomo la boz», A.C. 1512, 30-X-1512, fols. 43 r-v.

94 Testificaron contra él los arrendadores de las alcabalas Leonardo de la Serna y Alonso de Isla, A.C. 1500, 18-VII-1500, fols. 21 r y 21 v 22 r. Aparte de su labor profesional como escribano intentó ampliar su campo de acción a otras actividades, en las que su familia tenía cierta experiencia. Participó en la subasta de la renta de la Sisa en 1500 y 1502 e intentó arrendar la alcabala de las bestias en ese último año. Su padre Fernán Yáñez, arrendó la Sisa en 1499 y fue fiador del arrendador de la misma en 1503. Su tío, Alonso Yáñez, obligó el abastecimiento de pescado a la ciudad numerosas ocasiones (1492, 1494, 1495, 1496, 1497 y 1502), arrendó el ejido del estiércol de San Francisco en 1498 y fue receptor de la renta del Corretaje en 1498.

95 A.C. 1503 , 4-XI-1503, fol. 81 r: obedeciendo la orden del pesquisidor, volvió a presentar su título de escribano real. Se le vuelve a acusar de cobrar derechos excesivos «de los abtos que ante el pasan», limitándose el pesquisidor a hablar con el arrendador de las alcabalas para que «no se lleven costas demasiadas a los vezinos», 19-XII-1503, fol. $92 \mathrm{v}$. 


\title{
APENDICE DOCUMENTAL
}

\begin{abstract}
1492-V-28, Córdoba. Provisión real ordenando al corregidor de Murcia que se guarde una ordenanza de los capítulos de corregidores inserta sobre ante quien han de pasar las causas criminales, pues los escribanos del juzgado de la ciudad han presentado una serie de quejas sobre la actuación de los corregidores en este asunto (AGS, RGS, fol. 338).
\end{abstract}

Don Fernando e doña Ysabel, por la graçia de Dios rey e reyna de Castilla, de Leon, de Aragon, de Seçilia, de Granada, de Toledo, de Valençia, de Galizia, de Mallorcas, de Seuilla, de Çerdeña, de Cordoua, de Corçega, de Murçia, de Jahen, de los Algarbes, de Algezira, de Gibraltar, conde e condesa de Barçelona, señores de Vizcaya e de Molina, duques de Atenas e de Neopatria, condes de Rusellon e de Çerdania, marqueses de Oristan e de Goçiano. A vos, el que es o fuere nuestro corregidor o juez de regidençia de la çibdad de Murçia, salud e graçia.

Sepades que Françisco de Ayerbe, escriuano del judgado de la dicha çibdad, por si e en nonbre de los otros escriuanos del judgado de la dicha çibdad, nos fizo relaçion por su petiçion que ante nos en el nuestro consejo presento, diziendo que deuiendo como deven pasar ante ellos todos los abtos, asy çeuiles como criminales, que en la dicha çibdad se fazen ante vos las dichas justiçias, que vos los dichos corregidores e alcaldes e juezes de residençia tomays vn escriuano qual quereys ante quien pasen las cabsas criminales de la dicha çibdad, e arrendays la dicha escriuania del dicho crimen o llevays parte de los derechos de ella, no lo podiendo ni deuiendo fazer, seyendo como es en su grand agrauio e perjuizio e avn en dapno de la dicha çibdad, porque algunas vezes acaesçe que poneys escriuano de fuera de ella e que espirando vuestro ofiçio, se lleva los proçesos de ella e no queda razon ni cuenta de ellos, e nos suplico e pidio por merçed que sobre ello proueyesemos de remedio con justiçia o como la nuestra merçed fuese.

E nos tovimoslo por bien, e por quanto en las ordenanças que nos avemos mandado fazer para los corregidores e juezes de regidençia de las çibdades e villas de nuestros reynos de lo que han de guardar el tienpo que touieren los dichos ofiçios ay vna ordenança que sobre esto fabla, su thenor de la qual es este que se sigue:

Otrosy, que las abdiençias e otros abtos de justiçia los fagan todos ante los escriuanos del numero de la çibdad o villa donde ouiere de conosçer, sy alli oviere escriuanos del numero, e no tome otro ningund escriuano saluo vno para resçebir quexas e tomar las primeras ynformaçiones de los crimenes e para prender a los que por la ynformaçion fallaren culpantes, por se guardar mejor el secreto; e esto fecho, se remita ante escriuano publico, sy lo oviere, para que los proçesos criminales se fagan en la carçel, adonde este vn arca en que se guarden los dichos proçesos, la qual este a buen recabdo e aya libro de todos los proçesos que vinieren a la carçel, declarando cada vno porque fue preso e por cuyo mandado e los bienes que ouiere traydo, e quando se soltare se ponga al pie de dicho asyento el mandamiento porque fuere suelto. 
Porque vos mandamos que veays la dicha ordenança que de suso va encorporada e la guardeys e cunplays e fagays guardar e conplir en todo e por todo segund que en ella se contiene, e en guardandola e cunpliendola no vos entremetays ni consintays que escriuano alguno se entremeta en las cabsas criminales de mas e allende de lo contenido en la dicha ordenança e contra el thenor e forma de ella no vayays ni paseys ni consyntays yr ni pasar en tienpo alguno ni por alguna manera so pena de la nuestra merçed e de $\mathrm{x} V$ [maravedis], etcetera.

Dada en Cordoua, XXVIII de mayo de I V II'II XCII años. Don Aluaro. Johanes, liçençiatus de Talavera. Ispalensis. Johanes, dottor. Antonius, dottor. Françiscus, liçençiatus. Petrus, dottor. Yo, Alfonso del Marmol, escriuano de camara del rey e de la reyna nuestros señores, la fiz escreuir por su mandado con acuerdo de los del su consejo.

II

1494-IV-, Medina del Campo. Provisión real ordenando al corregidor de Murcia el envío ante el Consejo Real de los aranceles judiciales existentes en la ciudad, pues el concejo se ha quejado de que la justicia, escribanos y otros oficiales cobran derechos excesivos (AGS, RGS, fol. 312).

Don Fernando e doña Ysabel, etcetera. A vos el nuestro corregidor de la çibdad de Murçia, salud e graçia.

Sepades que Diego de Ayala, vezino e regidor de esa dicha çibdad, nos hizo relaçion por su petiçion diziendo que la dicha çibdad e vezinos de ella han reçibido e reçiben mucha vexaçion e fatiga, asy de los que tienen el cargo de la justiçia en ella como de los escriuanos e otros ofiçiales que ay en la dicha çibdad, porque les fan [sic] lleuado e lleuan muchos derechos, penas e caloñas e escrituras e otros abtos e cosas que ante ellos pasan, çerca de lo qual nos suplico e pidio por merçed con remedio de justiçia mandasemos proueer o como la nuestra merçed fuese.

E porque nos queremos mandar ver en el nuestro consejo el aranzel o aranzeles que en hesa dicha çibdad ay por donde se lleuan los dichos derechos para lo mandar proueer como cunpla a nuestro seruiçio e al bien de la dicha çibdad, por esta nuestra carta vos mandamos que del dia que vos fuere notificada fasta $\mathrm{xxx}$ dias primeros syguientes enbieys ante nos al nuestro consejo todos los aranzeles que ay en hesa dicha çibdad por donde se lleuan qualesquier derechos, asy las justiçias e escriuanos de esa dicha çibdad como otras qualesquier personas, porque lo mandemos ver e proueer segund dicho es.

E no fagades ende al, etcetera.

Dada en la villa de Medina del Canpo a [en blanco] dias del mes de abril de XCIIII años [sin firmas]. 
III

\section{2-VI-23, Toledo. Provisión real ordenanando al corregidor de Murcia que se informe de todos los derechos que cobran los escribanos del número y si perciben derechos excesivos, lo castigue (A.M.M., C.A.M., vol. V, n 76).}

Don Fernando e doña Ysabel por la graçia de Dios rey e reyna de Castilla, de Leon, de Aragon, de Seçilia, de Granada, de Toledo, de Valençia, de Galizia, de Mallorcas, de Seuilla, de Çerdeña, de Cordoua, de Corçega, de Murçia, de Jaen, de los Algarbes, de Algezira, de Gibraltar e de las yslas de Canaria, conde e condesa de Barçelona e señores de Vizcaya e de Molina, duques de Athenas e de Neopatria, condes de Rosellon e de Çerdania, marqueses de Oristan e de Goçiano. A vos, el que es o fuere nuestro corregidor o juez de residençia de la çibdad de Murçia o a vuestro alcalde en el dicho ofiçio e a cada vno o qualquier de vos a quien esta nuestra carta fuere mostrada, salud e graçia.

Sepades que Diego de Ayala, vezino e regidor de esa dicha çibdad, nos fizo relaçion por su petiçion que ante nos en el nuestro consejo presento, diziendo que en la dicha çibdad ay çiertos escriuanos del numero ante quien pasan las partiçiones de bienes y herençia de los vezinos de la dicha çibdad, e que muchas vezes en el ayuntamiento de la dicha çibdad los dichos vezinos se an querellado, diziendo que los tales escriuanos les lievan e an llevado grandes contyas de maravedis por hazer las dichas partiçiones, a vnos çinco e seys mill maravedis e a otros nueve e diez mill maravedis e que, avnque la dicha çibdad sobre ello a ordenado moderando los tales abtos e derechos, syenpre se a corronpido e deshordenado syn aver ninguna execuçion ni castigo, en lo qual la comunidad e bezinos de la dicha çibdad diz que an reçibido e reçiben mucho agrauio e daño, por ende, que nos suplicaua e pedia por merçed çerca de ello mandasemos proueer de remedio con justiçia [o] como la nuestra merçed fuese.

Lo qual, visto en el nuestro consejo, fue acordado que deviamos mandar dar esta nuestra carta en la dicha razon e nos tovimoslo por bien, porque vos mandamos que luego veades lo susodicho e llamadas e oydas las partes a quien atañe, vos ynformeys e sepais la verdad por quantas formas e maneras mejor e mas conplidamente lo pudieredes saber que derechos son los que antyguamente los dichos escriuanos solian e acostunbravan llevar de las dichas partiçiones y herençias e de los abtos y escrituras que sobre esto ante ellos pasan e que es lo que la dicha çibdad de Murçia despues ordeno e modero çerca de los susodichos derechos e que derechos son los que despues aca an llevado e llevan los dichos escriuanos por razon de lo susodicho e de todo lo otro que vos vieredes que vos deveys ynformar para mejor saber la verdad çerca de ello, e la dicha ynformaçion avida e la verdad sabida, sy por ella fallaredes que los dichos escriuanos o alguno de ellos an llevado algunos derechos demasiados de los que devian aver e llevar, los pugnays [sic] e castigueys segund e como de justiçia devades, conforme a las leys de nuestros reynos, e la ynformaçion que çerca de lo susodicho ovieredes con la relaçion de lo que [çerca=roto] de ello fisieredes e executaredes, lo enbiad todo ante nos al nuestro consejo, escrito en linpio e fyrmado de vuestro nonbre e sygnado del escriuano por ante quien pasare, çerrada e sellada en manera que faga fee, con vuestro pareçer de lo que en ello se deve proueer, para que lo mandemos ver e proueer çerca de ello lo que fuere justiçia, e entretanto que lo 
susodicho se ve e determina, sy vos paresçiere que los dichos derechos que llevan los dichos escriuanos por razon de lo susodicho son exçesyvos e demasiados de lo que deven aver e llevar, vos mandamos que taseys e modereys los dichos derechos como a vos pareçiere, para que aquellos lleven e no otros algunos, fasta que por nos sea visto e determinado lo susodicho, la qual dicha tasaçion vos mandamos que asymismo nos enbieys juntamente con la dicha ynformaçion como dicho es.

E no fagades ende al por alguna manera so pena de la nuestra merçed e de diez mill maravedis para la nuestra camara.

Dada en la çibdad de Toledo, a veynte e tres dias del mes de junio, año del nasçimiento de Nuestro Señor Ihesuchristo de mill e quinientos e dos años. Don Aluaro. Joanes, episcopus carthaginensis. Johanes, doctor. Liçençiatus Alonso. Martinus, doctor. Archipreste de Talauera. Fernandus Tello, liçençiatus. Liçençiatus Muxica. Yo, Bartolome Ruyz de Castañeda, escriuano de camara del rey e de la reyna nuestros señores, la fize escreuir por su mandado con acuerdo de los del su consejo. Registrada: Liçençiatus Polanco. Françisco Diaz, chançiller.

1505-I-31, Toro. Carta real de merced de Juan García de Medina como escribano del juzgado de la ciudad de Murcia, en lugar de Salvador de Villagómez, que perdió dicha escribanía al matar «malamente» a Juan de la Parrilla (A.M.M., C.R. 1494-1505, fol. 249 r).

Doña Juana por la graçia de Dios reyna de Castilla, de Leon, de Granada, de Toledo, de Gallizia, de Seuilla, de Cordova, de Murçia, de Iahen, de los Algarbes, de Algezira, de Gibraltar e de las yslas de Canaria, señora de Vizcaya e de Molina, prinçesa de Aragon e de Siçilia, archiduquesa de Avstria, duquesa de Borgoña, etçetera.

Por fazer bien e merçed a vos, Juan Garçia de Medina, mi escriuano publico e del numero de la çibdad de Murçia, acatando vuestra sufiçiençia e abilidad, es mi merçed e mando que agora e de aqui adelante para en toda vuestra vida seades mi escriuano del juzgado de la çibdad de Murçia en lugar e por vacaçion de Saluador de Villagomez, mi escriuano del juzgado que fue de la dicha çibdad, por quanto el dicho Saluador de Villagomez fue priuado del dicho ofiçio porque mato malamente a Juan de la Parrilla, e por ello fue condepnado a pena de muerte.

E por esta mi carta o por su treslado sygnado de escriuano publico mando al conçejo, justiçia, regidores, caualleros, escuderos, ofiçiales e omes buenos de la dicha çibdad de Murçia que juntos en su cabildo e ayuntamiento, segund que lo auedes de vso e de costunbre, resçiban de vos el dicho Juan Garçia de Medina el juramento e solepnidad que en tal caso se requiere, el qual por vos fecho, vos ayan e thengan e resçiban por nuestro escriuano del dicho juzgado en lugar del dicho Saluador de Villagomez e vsen con vos en el dicho ofiçio e vos recudan e fagan recudir con todos los derechos e salarios e otras cosas al dicho ofiçio anexas e pertenesçientes, segund que mejor e mas conplidamente recudieron e hizieron e devieron recudir al dicho Saluador de Villagomez e a los otros 
mis escriuanos que an seido e son del dicho juzgado e vos guarden e fagan guardar todas las onras, graçias, merçedes, franquezas e libertades, perrogativas, preminençias e ynmunidades e todas las otras cosas e cada vna de ellas que suelen e deven ser guardadas a cada vno de los otros mis escriuanos que an seido e son del dicho juzgado, de todo bien e conplidamente en guisa que vos no mengue ende cosa alguna e que en ello ni en parte de ello enbargo ni contrario alguno no vos pongan ni consientan poner, ca yo por la presente vos resçibo e he por resçibido al dicho ofiçio e al vso [e] exerçiçio de el, e vos doy poder e facultad para lo vsar [e] exerçer caso puesto que por los susodichos o por alguno de ellos no seades resçibido a el.

E por evitar los perjuros e fraudes e costas e daños que de los contratos fechos con juramento e de las sumisiones que se hasen cabtelosamente se siguen, mando que no signeys contrato con juramento ni por donde lego alguno se someta a la juresdiçion eclesiastica ni que se obligue a buena fe syn mal engaño, so pena que sy lo signaredes ayays perdido e perdays el dicho ofiçio.

E otrosy, con tanto que no seays al presente clerigo de corona e sy lo soys o fueredes de aqui adelante, por el mismo caso, ayays perdido e perdays la dicha escriuania e no seays mas mi escriuano del dicho juzgado ni vseys del dicho ofiçio, so pena que sy lo vsaredes, por el mismo fecho, seays avido por falsario syn otra sentençia ni declaraçion alguna.

E los vnos ni los otros no fagades ni fagan ende al por alguna manera so pena de la mi merçed e de diez mill maravedis para la mi camara e demas mando al ome que vos esta mi carta mostrare que vos enplaze que parezcades ante el rey mi señor e padre en la mi corte, do quier que su señoria sea, del dia que vos enplazare fasta quinze dias primeros siguientes so la dicha pena, so la qual mando a qualquier escriuano publico que para esto fuere llamado que de ende al que vos la mostrare testimonio signado con su signo, porque yo sepa como se cunple mi mandado.

Dada en la çibdad de Toro, a treynta e vn dias del mes de henero, año del nasçimiento de Nuestro Saluador Ihesuchristo de mill e quinientos e çinco años. Yo el rey. Yo, Juan Ruiz de Calçena, secretario de la reyna nuestra señora, la fiz escreuir por mandado del señor rey su padre, como administrador y governador de estos sus reynos. E en las espaldas de la dicha carta estan escriptos los nonbres syguientes: Françiscus Tello, liçençiatus. Liçençiatus Moxica. Doctor Caravajal. Liçençiatus de Santiago. Registrada: Liçençiatus Polanco, Luys del Castillo, chançiller.

1506-VIII-25, Valladolid. Provisión real ordenando al corregidor de la ciudad de Murcia a que obligue a los 18 escribanos del número a que atiendan su obligación, pues el abandono de la misma estaba causando graves perjuicios a los vecinos (A.M.M., C.R. 1505-1514, fols. 7 v 8 r).

Don Felipe e doña Juana, por la graçia de Dios rey e reyna de Castilla, de Leon, de Granada, de Toledo, de Galizia, de Seuilla, de Cordoua, de Murçia, de Jaen, de los Algarbes, de Algezira e de Gibraltar e de las yslas de Canaria e de las Yndias e Tierra Firme 
del Mar Oçeano, prinçipes de Aragon e de las Dos Siçilias e de Iherusalen, archiduques de Avstria, duques de Borgoña e de Bravante, etc, condes de Flandes e de Tirol, etc, señores de Vizcaya e de Molina, etc. A vos, el que es o fuere nuestro corregidor o juez de resydençia de la çibdad de Murçia o a vuestro alcalde en el dicho ofiçio, salud e graçia.

Sepades que por parte del conçejo, justiçia, regidores, caualleros, escuderos, ofiçiales e omes buenos de esa dicha çibdad de Murçia nos fue fecha relaçion por su petiçion diziendo que en la dicha çibdad ay diez e ocho escriuanos del numero de ella, e algunos de ellos entienden en sus faziendas e en tratar en mercaderias e en otras cosas, a cabsa de lo qual diz que no vsan ni exerçen sus ofiçios como deven, de manera que las personas que tienen de otorgar algunas escrituras ante ellos no las pueden aver para las otorgar, a cabsa de lo qual diz que resçiben mucho agrauio e daño, porque por no tener ante quien otorgar las dichas escrituras e otros abtos se conçiertan e ygualan con las partes e pierden mucho de sus faziendas, por ende, que nos suplicavan e pedian por merçed que mandasemos que los dichos escriuanos estuviesen en lugares e partes donde fuesen fallados, para que quando los quisyesen e ovieren menester para fazer e otorgar qualesquier escrituras e otros abtos, o como la nuestra merçed fuese.

Lo qual visto en el nuestro consejo fue acordado que deviamos mandar dar esta nuestra carta para vos en la dicha razon, e nos tovimoslo por bien, porque vos mandamos que luego veades lo suso dicho e proueays en ello como con justiçia devays e mas vieredes que conviene al bien e pro comun de esa dicha çibdad, por manera que los dichos escriuanos esten en lugares e partes donde las personas que ante ellos quisyeren fazer e otorgar algunas escrituras e fazer otros qualesquier abtos los fallen quando ovieren menester, e a cabsa de ello no resçiban daño en sus faziendas.

E los vnos ni los otros no fagades ende al por alguna manera so pena de la nuestra merçed e de diez mill maravedis para la nuestra camara. Dada en la villa de Valladolid, a veynte e çinco dias del mes de agosto año del nasçimiento de Nuestro Saluador Ihesuchristo de mill e quinientos e seys años. Petrus, dottor. Liçençiatus Muxica. Dottor Caravajal. Liçençiatus de Santiago. Joanes, doctor. Liçençiatus Polanco. Yo, Juan Ramirez, escriuano de camara del rey e de la reyna nuestros señores, la fize escreuir por su mandado con acuerdo de los del su consejo, e en las espal[d]as dezia estos nonbres: Registrada, Pedro de Laguna. Castañeda, chançeller.

\section{RELACION NOMINAL DE ESCRIBANOS}

Abellán, Francisco: escribano del juzgado (?-1488)

Abellán, Pedro: escribano del juzgado (1492-1493)

Alcaraz, Pedro de: escribano del número (?-1491)

Alvarez de Toledo, Alfonso: escribano mayor de rentas del obispado de Cartagena (?-?)

Arróniz, Sancho de: regidor, escribano de la Aduana de la ciudad de Murcia (14841498)

Auñón, Alonso de: jurado, escribano mayor de rentas del obispado de Cartagena (1495-?) y escribano del número (?-1499)

Ayerbe, Francisco de: escribano del juzgado (1490-1496) 
Belzunce, Alonso: escribano del número (1488-?) real y apostólico

Bernad, Antón: escribano del número (1492-1496)

Bernal de Palomeque, Alonso: escribano del número (1499-1514) y apostólico

Borovia, Bartolomé de: escribano del número (1507-?)

Borovia, Martín de: escribano del número (1514-?)

Cascales, Juan de: regidor, escribano de la Aduana de la ciudad de Murcia (?-1484)

Castillo, Fernando del: escribano del número (?-1495)

Castillo, Francisco del: escribano del número (1491-?) y apostólico

Castillo, Juan del: escribano del número (1510-1515)

Conde, Luis: escribano del número (1515-?)

Contreras, Miguel de: escribano del juzgado (1493-1497)

Contreras, Francisco de: escribano del número (1508-?)

Coque, Bartolomé: escribano del número (1488-1510) y real

Cueva, Juan de la: escribano del número (1491-1497)

Escarramad, Francisco: escribano del juzgado (1462-1488)

Fernández de Mojados, Alonso: escribano de la Inquisición (1500)

Fernández de Alarcón, Bartolomé: escribano del número (1496-1508)

Fernández, Antón: escribano del número (?-1484)

Fernández de Pineda, Juan: escribano real (1503)

Herrera, Rodrigo de: escribano de los Diezmos y Aduanas de Aragón (1480)

Ibáñez, Pedro: escribano del número (1506-?)

Jaca, Martín de: escribano del número (1512-?)

Jiménez de Medrano, Juan: escribano del número (?-1498) y del juzgado (1491-1500)

Lara, Diego de: regidor, escribano de los Diezmos y Aduanas de Aragón (1515-?)

López, Pedro: escribano del número (1469-1513), del juzgado (1488-1490), apostólico y real

López, Diego: escribano del número (1500-1512)

López, Pedro: escribano del número (1513-?)

Lorenzo, Martín: escribano del número (1496-1508)

Martínez, Pedro: fiel de la escribanía de la Aduana de la ciudad de Murcia (1503-1510) y de los Diezmos y Aduanas de Aragón (1499-?)

Mateo, Diego: fiel de la escribanía de la Aduana de la ciudad de Murcia (1498-1503) y de los Diezmos y Aduanas de Aragón (1499-?)

Medina, Juan de: escribano del número (1498-?), del juzgado (1505-?) y real

Núñez de Astudillo, Juan: escribano del número (?-1484)

Núñez, Pedro: escribano del número (?-1491)

Núñez de Lorca, Pedro: escribano de los Diezmos y Aduanas de Aragón (1479-1480)

Ñúnez de Lorca, Lope: escribano de los Diezmos y Aduanas de Aragón (?-1479)

Palazol, Alonso de: escribano del número (?-1499) y del concejo (1481-1499)

Palazol, Francisco de: escribano del número (1491-1510), del concejo (1499-?) y real

Pellicer, Diego: escribano del número (1508-?)

Pérez Beltrán, Francisco: escribano del concejo (?-1481)

Pérez Beltrán, Francisco: escribano del número (1495-1506)

Pérez Corella Fajardo, Ximén: escribano de la Aduana de la ciudad de Murcia (1510-?) 
Pérez de Monzón, Fernán: escribano del número (1491-1496) y del juzgado (14981503)

Pérez de Monzón, Alfonso: escribano del número (?-1469)

Pérez de Bonmaitin, Garci: escribano del número (1506-?)

Periñíguez, Simón: escribano del número (1507-?)

Pina, Bernardino de: escribano del número (1484-?), real y apostólico

Piñero, Juan: escribano del número (1499-1507)

Plaza, Francisco de la: escribano del juzgado (1503-?) y de la Inquisición (1503)

Riquelme, Diego: escribano del número (1464-1507), del juzgado (1488-1491) y real

Riquelme, Juan: escribano del número (?-1481)

Rodríguez de Bustamante, Juan: escribano del número (1491-1508) y real

Rodríguez de Alcaraz, Antón: escribano del juzgado (1488-1492)

Rodríguez de Almela, Alonso: escribano del juzgado (1496-1497)

Rodríguez, Antón: escribano del número (1484-1492)

Rodríguez, Bartolomé: escribano del número (?-1491)

Rodríguez de Alcaraz, Alfonso: escribano del número (1485-?)

Romi, Luis: escribano real (1490)

Ruíz, Diego: fiel de la escribanía de la Aduana de la ciudad de Murcia (1495-?)

Ruíz, Luis: escribano del número (?-1499)

Sánchez de las Doncellas, Alonso: fiel escribanía Diezmos y Aduanas de Aragón (14881499) y escribano real

Santa María, Lope de: escribano del número (1482-1491)

Santa María, Pedro de: escribano del número (1462-1485)

Santesteban, Alvaro de: regidor, escribano de los Diezmos y Aduanas de Aragón (14881515)

Segovia, Juan de: escribano del número (1510-?)

Sevillano, Antón: escribano del número (1491-1506), del juzgado (1497-1506) y real

Sevillano, Rodrigo: escribano del número (1484-1491)

Sevillano, Alfonso: escribano del número (1481-1491)

Soria, Diego de: escribano del número (1496-1508)

Soto, Diego de: escribano del juzgado (1497)

Tordesillas, Juan de: escribano del número (1497-?)

Valcárcel, Francisco de: escribano del número (1499-1500) y del juzgado (1506-1514)

Villagómez, Salvador de: escribano del juzgado (1500-1504)

Yáñez, Juan: escribano real (1495)

Yáñez, Fernán: escribano del número (1459-1488) 
